SANDIA REPORT

SAND95-2692 • UC-1290

Unlimited Release

Printed November 1995
RECEIVED

JAN 251996

OSTI

\title{
Superior Valley Photovoltaic Power Processing Hardware and System Controller Evaluation
}

Russell Bonn, Jerry Ginn, Jeff Zirzow, Greg Sittler

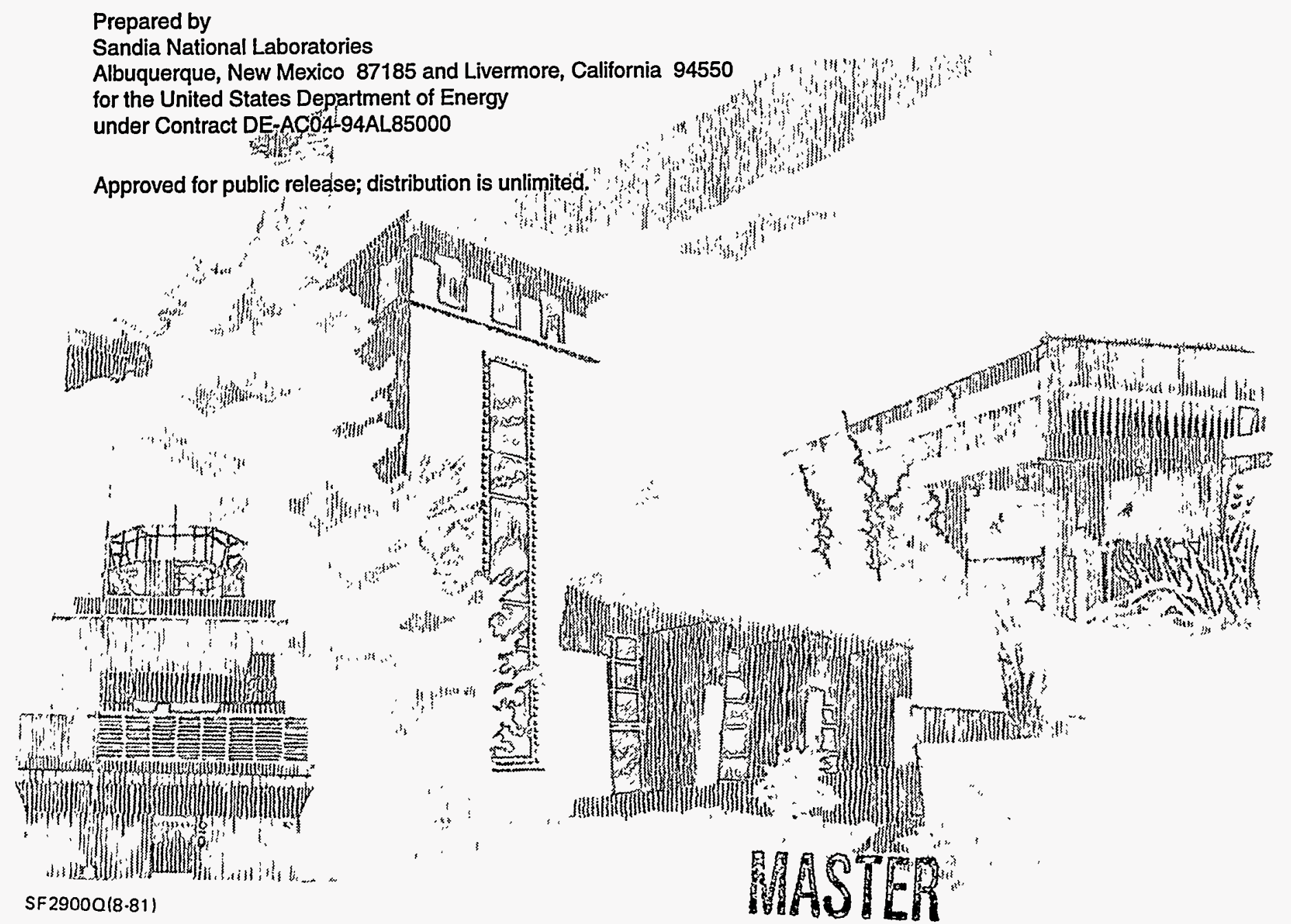


Issued by Sandia National Laboratories, operated for the United States Department of Energy by Sandia Corporation.

NOTICE: This report was prepared as an account of work sponsored by an agency of the United States Government. Neither the United States Government nor any agency thereof, nor any of their employees, nor any of their contractors, subcontractors, or their employees, makes any warranty, express or implied, or assumes any legal liability or responsibility for the accuracy, completeness, or usefulness of any information, apparatus, product, or process disclosed, or represents that its use would not infringe privately owned rights. Reference herein to any specific commercial product, process, or service by trade name, trademark, manufacturer, or otherwise, does not necessarily constitute or imply its endorsement, recommendation, or favoring by the United States Government, any agency thereof or any of their contractors or subcontractors. The views and opinions expressed herein do not necessarily state or reflect those of the United States Government, any agency thereof or any of their contractors.

Printed in the United States of America. This report has been reproduced directly from the best available copy.

Available to DOE and DOE contractors from

Office of Scientific and Technical Information

PO Box 62

Oak Ridge, TN 37831

Prices available from (615) 576-8401, FTS 626-8401

Available to the public from

National Technical Information Service

US Department of Commerce

5285 Por Royal Rd

Springfield, VA 22161

NTIS price codes

Printed copy: A03

Microfiche copy: A0I 
SAND95-2692

Unlimited Release

Printed November 1995

\title{
Superior Valley \\ Photovoltaic Power Processing and System Controller Evaluation
}

\author{
Russell Bonn, Jerry Ginn, Jeff Zirzow, Greg Sittler \\ Photovoltaic Systems Applications Department \\ Sandia National Laboratories \\ Albuquerque, New Mexico 87185
}

\begin{abstract}
Sandia National Laboratories, sponsored by the US Department of Energy's Office of Energy Management, conducts the photovoltaic balance-of-system program. Under this program, Sandia supports the Department of Defense Strategic Environmental Research Development Plan, SERDP, which is advancing the use of photovoltaics in operational DoD facilities. This report details the acceptance testing of the first of these photovoltaic hybrid systems: the Superior Valley photovoltaic-diesel hybrid system. This is the first of several photovoltaic installations for the Department of Defense. The system hardware tested at Sandia included an inverter, maximum power trackers, and a system controller.
\end{abstract}





\section{TABLE OF CONTENTS}

Executive Summary

1.0 Overview

Table 2.1: Report of Planned Test Parameters

2.0 Standard Test Elements

3.0 Detailed Test Report

3.1 System Burn-in

3.2 System Control

3:2.1 Safety

3.2.1.1 Critical Failure Alarm

3.2.1.2 Smoke Alert

3.2.2 Monitors and Manual Controls

3.2.2.1 Status Monitors

3.2.2.2 Manual Controls

3.2.3 Battery Health and Maintenance

3.2.3.1 Battery Charging Cycle

3.2.3.2 Battery Equalization Schedule

3.2.3.3 Full Generator Utilization

3.2.3.4 Protection from battery over discharge

3.3 Inverter Power Quality and Performance

3.3.1 Rated Power

3.3.2 Efficiency

3.3.2.1 Inverter Efficiency

3.3.2.2 Charge Mode Efficiency/Charge Power

3.3.3 Transfer of Sources

3.3.4 Reactive/Nonlinear Loading

3.3.5 Transient Loading

3.3.6 Inverter RFI

3.4 Electrical Transient Protection - Tests not conducted at SNL

3.5 Maximum Power Tracker Evaluation

3.5.1 Effective dc Range

3.5.2 Efficiency

3.5.3 MPT RFI 


\section{FIGURES}

Figure 1: Battery Power for first part of burn-in test 7

Figure 2: Battery Power for second part of burn-in test 7

Figure 3: Battery Power for final part of burn-in test 8

Figure 4: Example of full utilization of the generator 15

Figure 5: Transient response for $10 \mathrm{~kW}$ to $90 \mathrm{~kW}$ load step 17

Figure 6: Step load response for $27 \mathrm{~kW} /$ phase to $90 \mathrm{kVA}, .8 \mathrm{PF}$, Phase A 18

Figure 7: Voltage regulation and phase-to-phase imbalance 19

Figure 8: Phase voltages with unbalanced resistive load 19

Figure 9: Phase voltages for a balanced $198 \mathrm{kVA}, .72 \mathrm{PF} \quad 20$

Figure 10: Inverter loading at $314 \mathrm{~kW} \quad 20$

Figure 11: Inverter efficiency with resistive loading 21

Figure 12: Transfer from generator to inverter with $100 \mathrm{~kW}$ load 22

Figure 13: Transfer from Inverter to Generator with $100 \mathrm{~kW}$ load 23

Figure 14: Addition of $150 \mathrm{~kW}$ of charge power to $150 \mathrm{~kW}$ of load power, $\quad 24$

Figure 15: Nonlinear loading with 5.65\% voltage total harmonic distortion 27

Figure 16: Inverter distortion for various loads $\quad 27$

Figure 17: Generator distortion for various loads 28

Figure 18: Using generator as source - $135 \mathrm{~kW}$ charge \& $150 \mathrm{~kW}$ load 29

Figure 19: Air conditioner startup transient with $145 \mathrm{~kW}$ base load 30

Figure 20: Block load testing of inverter, $198 \mathrm{kVA}, .72 \mathrm{PF}$

Figure 21: Ten second, $120 \mathrm{kVA}$, load 31

Figure 22: MPT efficiency 33

Figure 23: Noise spectrum for inverter with $150 \mathrm{~kW}$ load 34

Figure 24: Noise spectrum charging battery at $87 \mathrm{~kW} \quad 34$

Figure 25: Noise spectrum of background $\quad 35$

\section{TABLES}

Table 1: Results of MDOD test 9

Table 2: Battery over voltage test 9

Table 3: Battery cell out-of-tolerance test 10

Table 4: Detection of ground fault 10

Table 5: Frequency deviation test 11

Table 6: Observed status functions $\quad 12$

Table 7: Status functions that were not observed 13

Table 8: Steady-state measurements across load transitions $\quad 17$ 


\section{Executive Summary}

This test report documents the acceptance testing of the inverter, selected maximum power trackers (MPTs), and the control system for the $300 \mathrm{~kW}$, Superior Valley hybrid photovoltaic-diesel system. This hybrid photovoltaic system will be installed at a remote site on the Naval Air Warfare Center- Weapons Division in China Lake, California. This is the first of several photovoltaic systems that will be installed in Department of Defense installations. This turnkey system is composed of twelve photovoltaic (PV) arrays, twelve Abacus Controls $25 \mathrm{~kW}$ maximum power trackers (MPTs), six Abacus Controls $50 \mathrm{~kW}$ bimode inverters, a system controller, $3,500 \mathrm{kWh}$ of batteries, and a $300 \mathrm{~kW}$ diesel generator. At Superior Valley, all twelve of the MPTs, all six of the inverters, and the four battery strings are tied to the same dc bus. The inverter output power of $100 \mathrm{~kW} / \mathrm{ph}$ ase is supplied by two $50 \mathrm{~kW}$ inverters in parallel. The $240 \mathrm{Vac}$ output of the inverters is coupled through an isolation transformer and RFI filter to a wye transformer which is in turn coupled to the load. In addition, the $125-275 \mathrm{~kW}$ radar load voltage of 416 volts is supplied by the phase-to-phase voltage, which is not transformer coupled.

Although the test results reported herein are accurate for the equipment tested at Sandia, the power processing hardware, such as reported on, are not mass produced, production-line devices. It may be many months before a second unit similar to this one is ordered, during which time power processing concepts evolve, and new devices become available. In many ways each power processing system is custom built. Therefore, a rigorous field start-up procedure should be anticipated for any new installation of such hardware. When sufficient quantities of this hardware are being installed, the field start-up problems will diminish.

Because this was the first time a system like this had been assembled, the test was a combination of development and acceptance testing. Several development problems were encountered and corrected during the course of the test. The hardware passed all of the acceptance criteria except that for total harmonic distortion (THD) when highly nonlinear loads were applied. In general the THD was acceptable. It is not anticipated that the THD of the fielded system will exceed the specification. 



\section{Superior Valley Test Results}

\subsection{Overview}

The hardware delivered to Sandia National Laboratories for acceptance testing included:

- one rack of four maximum power trackers (MPTs) (Abacus part number MPT-384),

- all six inverters (Abacus part number 554-5),

- one 75 kVA transformer (Abacus part number 23583)

- one controller system (Abacus part number SC300KW)

The test did

- configure up to four MPTs, all six inverters, the SNL battery bank (480 kWh @ 6 hour rate), a rented $570 \mathrm{kVA}$ diesel, and the controller into a system;

- conduct extensive performance tests on all of the six inverters;

- conduct extensive testing on one of the MPTs, and run at least two of them during most of the test to evaluate interaction problems.

Although some developmental testing was performed the primary focus of the testing was acceptance testing. The equipment was evaluated to determine compliance with the Superior Valley statement of work (SOW). Most of the parameters were compared to that specification (see figure 2.1). Quotes in this document refer to a particular specification in the SOW.

A rented diesel generator was used for full power testing. The parameters evaluated are listed in Table 2.1. The test was temporarily discontinued when any anomalous condition was observed. All tests were conducted at room temperature. A photo of the front of the master inverters and the rear of the slave inverters is shown below.

The Abacus inverter has met all of the evaluated specifications, except the one for voltage distortion when powering nonlinear loads. For similar loads it is noted that the THD from the inverter is less than the THD from the diesel.

Total distortion. (Sec 3.3.4) The total voltage harmonic distortion was $5.63 \%$ and the total voltage distortion was $6.1 \%$ when the load was

- phase $A=61 \mathrm{~kW}$, phase $B=39 \mathrm{~kW}$, phase $C=38 \mathrm{~kW}$

- $P F($ phase $A)=.7, P F($ phases $B \& C)=1$

- ac current distortion $=16.7 \%$.

In a second test, the total voltage distortion was $6.8 \%$ when the loading was

- phase $A=33.5 \mathrm{~kW}$, phase $B=15 \mathrm{~kW}$, phase $C=15 \mathrm{~kW}$

- $P F($ phase $A)=.58, P F($ phases $B \& C)=1$

- ac current distortion $=35 \%$.

Although the value of voltage total harmonic distortion exceeds specifications, it may not adversely affect equipment operation at Superior Valley. Also, increasing the resistive parallel load decreases the total distortion. With $100 \%$ resistive loads, the value for total voltage distortion is $<2.5 \%$.

Important Note: A $300 \mathrm{~kW}$ diesel generator was originally used in the SNL test bed. This diesel was unable to support a block load of more than $225 \mathrm{~kW}$. Block loading of the 
generator occurred when the inverter transferred to the diesel. This could result from either the inverter trying to charge batteries at large power rates or from a large inverter load. The block loading of the generator by the inverter in charge mode is easily changed. The initiation of charge can be delayed and the charge can be gradually initiated. However, when the inverter is fully loaded, the block load cannot be avoided unless the load is 'transferred gradually to the diesel. This requires that the inverter, which was operating as a voltage source in the stand-alone mode, be. transferred to a current source at the moment the generator is brought on line. The inverter load is then gradually transferred to the generator. This mode of operation will be available in future products of this type. Another solution is to oversize the generator; however this results in increased inefficiencies. To continue the test SNL did obtain a $500 \mathrm{~kW}$ diesel generator.
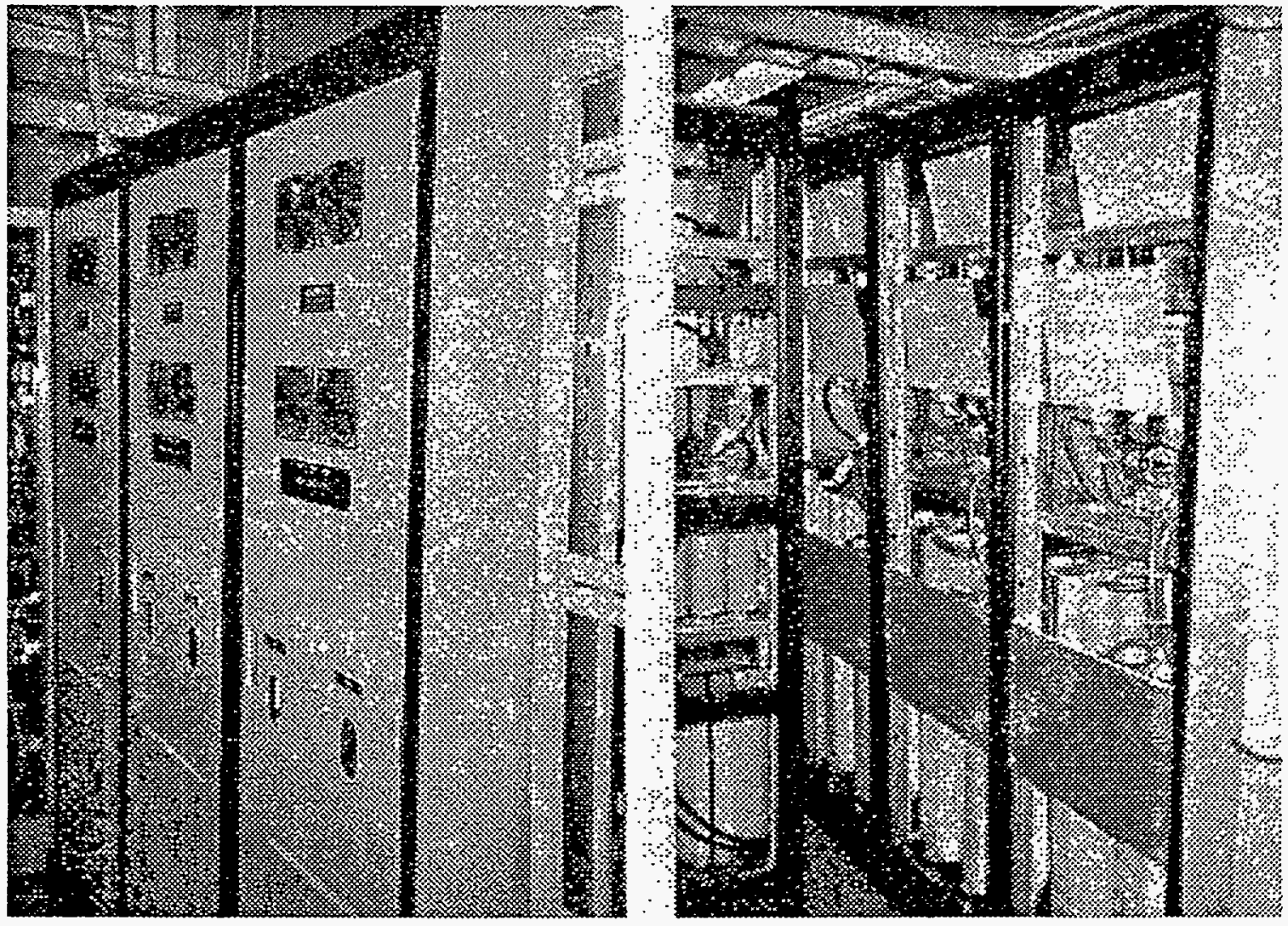

Photo 1: Front of master inverters and rear of slave inverters

In the paragraphs that follow, the results of evaluating important parameters are summarized. Each paragraph has a reference to a report paragraph that contains more detailed results.

Inverter Efficiency. (Sec 3.3.2.1) The inverter efficiency was not specified. The measured efficiency peak was $93.5 \%$ at $246 \mathrm{~kW}$. Other values included $83 \%$ at $3 \mathrm{~kW}$, $91.7 \%$ at $90 \mathrm{~kW}$, and $93.2 \%$ at $310 \mathrm{~kW}$.

Voltage Regulation ( $\operatorname{Sec} 3.3 .1$ ). The voltage regulation is specified to be $< \pm 5 \%$. While not specified, phase imbalance was also noted. The voltage regulation was better than $3.5 \%$ for all observed resistive load inverter conditions. A necessary exception occurs when transferring from inverter to generator. Since the inverter operates a few volts above the generator voltage, the setting of the generator voltage determines the inverter output voltage. The maximum change in inverter output voltage occurs when the generator shuts 
off. At that point, the inverter output voltage changed from $248 \mathrm{Vac}$ (the generator voltage plus 9 volts) to 240 Vac.

For an unbalanced load ( $18.3 \mathrm{~kW}$ on phases $B$ and $C, 86 \mathrm{kVA}, \mathrm{PF}=.74$ on phase $\mathrm{A}$ ), the phase $A$ voltage dropped from $239.5 \mathrm{Vac}$ to $231 \mathrm{Vac}$. The phases $A$ and $B$ voltages are up to 8 volts apart.- This is $3.5 \%$ voltage regulation on phase $A$ and a $3.3 \%$ phase imbalance between phases $A$ and $B$.

Inverter Power Rating (Sec 3.3.1). The inverter is rated at $100 \mathrm{kVA}$ continuous/phase and at $120 \mathrm{kVA} /$ phase for 10 seconds. The maximum rating was evaluated three ways. First, the inverter load was unbalanced with one phase at a time loaded to just over $100 \mathrm{~kW}$. Next, the inverter was loaded with a balanced load of $314 \mathrm{~kW}$ on the three phases; and finally phase A was surge loaded with $118 \mathrm{~kW}$ for 10 seconds. No problems were noted.

Source Transfer (Sec 3.3.3). Successful transfers were accomplished in both directions (e.g., inverter-to-generator and generator-to-inverter). Only very small transient perturbations were observed at the time of transfer. The transfers were successful.

Frequency Stability (Sec 3.3.1). The frequency stability is not specified. It was monitored and the largest observed frequency deviation (across a load transient) was observed to be $.1 \mathrm{~Hz}$.

Audible Noise (Sec 3.6). The audible noise was not specified. The largest recorded audible noise was $68 \mathrm{~dB}$ spl.

Charge Efficiency (Sec 3.3.2.2). The charge efficiency was measured over a dc charging power range of $136 \mathrm{~kW}$ to $282 \mathrm{~kW}$. The efficiency was $95 \pm .5 \%$ over the entire range. The efficiency at these power levels was independent of the charging power.

Maximum Measured Charge Power (Sec 3.3.2.2). The generator was loaded up to 302 $\mathrm{kW}$ with $282 \mathrm{~kW}$ of dc charge power and $3.5 \mathrm{~kW}$ of ac load power. At this power, the efficiency was $94.6 \%$

dc Ripple (Sec 3.2.3.1). The dc ripple was specified to be less than $2 \%$. The measured value was less than $.5 \%$.

Critical Alarms (Sec 3.2.1.1). Proper functionality of the critical alarms was verified.

Generator Control (Sec 3.2.2.2 and 3.2.3.3). The generator control was successfully exercised by both manual and automatic means.

Manual Control (Sec 3.2.2.2). The manual controls were successfully exercised.

System Controller. The system controller managed most functions properly. A few adjustments are expected after system installation at Superior Valley. 


\begin{tabular}{|c|c|c|}
\hline TP Para & $\begin{array}{l}\text { SOW Para } \\
\text { July } 13,94\end{array}$ & Parameter/function evaluated \\
\hline \multicolumn{3}{|r|}{ SOW performance criteria } \\
\hline \multicolumn{3}{|l|}{ scope } \\
\hline 3.1 .3 .1 & 1.2.e & load disconnect shall protect battery in event of system problem \\
\hline $\begin{array}{l}3.2 .1 .6 \& \\
3.2 .2 .2\end{array}$ & $1.2 . j$ & RFI power above $10 \mathrm{MHz}<8 \times 10-9$ watts/meter ${ }^{1}$ \\
\hline 3.2 .1 .1 & $1.2 . \mathrm{k}$ & $120 / 208 V \pm 5 \%$ \\
\hline \multicolumn{3}{|c|}{ system control } \\
\hline 3.1 .3 .1 & 3.1 .6 .2 & DOD $<70 \%$ \\
\hline 3.1 .3 .2 & 3.1 .6 .3 & battery equalization schedule \\
\hline 3.1 .3 .1 & 3.1 .6 .4 & load shedding at maximum DOD \\
\hline 3.1 .3 .1 & 3.1.6.5 & $\begin{array}{l}\text { generator control } \\
\text { start gen for battery charge \& equalization (redundant) } \\
\text { transfer load to gen (after start) } \\
\text { transfer load to inverter after charge or equalization }\end{array}$ \\
\hline 3.1 .2 .1 & 3.1 .6 .6 & $\begin{array}{l}\text { systems status indicator shall monitor the array, battery, status, generator, } \\
\text { grid power, and ground. }\end{array}$ \\
\hline 3.1 .1 .1 & 3.1.6.7.1 & $\begin{array}{l}\text { shall signal a critical failure } \\
\text { shall signal smoke \& transfer to diesel } \\
\text { alarm powered off battery bank }\end{array}$ \\
\hline 3.1 .2 .2 & $\begin{array}{l}3.1 .6 .8 \\
3.1 .6 .1\end{array}$ & $\begin{array}{ll}\text { manual controls } & \text { transfer load } \\
\text { start/stop generator } & \text { initiate battery equalization } \\
\text { initiate battery charge cycle } & \text { alarm reset } \\
\text { adjust ODOD } & \\
\text { emergency shut-down } & \end{array}$ \\
\hline $3.1 .1 .1 \& 2$ & 3.1 .6 .9 & emergency off \\
\hline \multicolumn{3}{|l|}{ transients } \\
\hline 3.3 & 3.1 .7 & lightning and transient/surge protection \\
\hline \multicolumn{3}{|l|}{ battery } \\
\hline 3.1.3.1 & 3.1.9.2.3 & charge controller shall regulate both PPS and array charge I \\
\hline \multicolumn{3}{|r|}{ 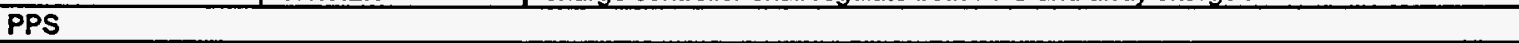 } \\
\hline $\begin{array}{l}3.2 .1 .1 \\
3.2 .1 .5\end{array}$ & $\begin{array}{l}3.1 .10 .1 .1 \\
(3.1 .10 .4 .1)\end{array}$ & $\begin{array}{l}\text { minimum output power rating of } 100 \mathrm{kVA} \text { continuous/phase surge output power } \\
\text { rating of } 120 \mathrm{kVA} \text { per phase for } 10 \mathrm{sec}\end{array}$ \\
\hline $\begin{array}{l}3.2 .1 .1 \\
8 \\
3.2 .4\end{array}$ & 3.1 .10 .1 .2 & $\begin{array}{l}\text { THD voltage distortion }<5 \% \text { ( } 3 \% \text { for an individual harmonic) for the following loads } \\
100 \mathrm{kVA} \text { continuous resistive load on each phase } \\
80 / 75 / 70 \mathrm{~kW}, .8 \mathrm{PF} \text { on each phase lagging } \\
60 / 55 / 45 \mathrm{~kW}, .7 \text { power factor lagging, } 20 \% \text { total current harmonic dist } \\
30 / 25 / 15 \mathrm{~kW}, .5 \text { power factor lagging, } 40 \% \text { total current harmonic dist }\end{array}$ \\
\hline 3.2 .1 .3 & 3.1 .10 .2 & $\begin{array}{l}\text { confirm that gen is operating within specs prior to transfer quantify transfer } \\
\text { transients }\end{array}$ \\
\hline 3.2 .1 .3 & 3.1 .10 .3 & synchronous and transient free transfer \\
\hline 3.1 .3 .3 & 3.1 .10 .4 .1 & rectifier shall have a min pwr rating of $100 \mathrm{kVA}$ ac continuous/phase \\
\hline 3.1 .3 .1 & 3.1 .10 .4 .2 & dc ripple $<2 \%$ RMS \\
\hline \multicolumn{3}{|r|}{ Additional Evaluation Parameters } \\
\hline 3.2 .1 .1 & & distortion \\
\hline 3.2 .1 .1 & & voltage sag \\
\hline 3.2 .1 .1 & & inverter efficiency \\
\hline 3.2 .1 .1 & & frequency stability \\
\hline 3.5 & & audible noise \\
\hline \multicolumn{3}{|r|}{ Maximum Power Tracker } \\
\hline 3.4 .1 & & dc operation range \\
\hline 3.4 .2 & & efficiency \\
\hline 3.3 & & transient surges \\
\hline
\end{tabular}

Table 2.1: Report of Planned Test Parameters

1. IEEE Std 1035-1989, "IEEE Recommended Practice: Test Procedure for UtilityInterconnected Static Power Converters". 


\subsection{Standard Test Elements}

The specifications in this report are drawn from the Superior Valley statement of work (SOW). All quotes in this document refer to that SOW. The following are standard settings or limitations that were encountered frequently throughout the test.

1. Because of the limited battery capacity at SNL (655 A @ 1 hour rate), it was possible to fully load all three phases only after battery equalization and then for only a short period of time.

2. Because parameter characterization may vary as a function of the input voltage, it is important to define nominal battery SOC. The "nominal" dc battery voltage is 384 volts dc (192 cells times 2). For the purpose of most of the following tests, an acceptable state of charge is $>85 \%$ (i.e., not more than $15 \%$ of the charge has been removed). This was referred to as the nominal state of charge (SOC).

3. Operational depth of discharge (ODOD) is defined in terms of percent of SOC as measured in amp-hours. This value can be adjusted from the system controller.

4. The minimum voltage allowed by the system controller during the test was $346 \mathrm{Vdc}$. This value is also referred to as the maximum depth of discharge (MDOD). This value is field adjustable.

5. If for any reason the dc voltage is reduced to 336 volts ( 1.75 volts/cell), the inverter firmware shuts the inverter down.

6. For the purpose of this test, a fully-loaded phase is defined as $100 \mathrm{kVA}$ with the generator disabled. 


\subsection{Detailed Test Report}

The measurement matrix (see appendix A) defines each measurement parameter and the transducer used for the measurement.

\subsection{System Burn-in}

One of the first tests at Sandia was a system burn-in test. The purpose of the test was to identify infant mortality failures and system operating problems.

\section{Detailed Test Procedure.}

The test plan called for exercising the inverter bridges at approximately $150 \mathrm{~kW}$ ax for 18 hours. Assuming an average battery voltage of $400 \mathrm{Vdc}$ and $91 \%$ efficiency, this corresponded to $165 \mathrm{~kW}(\sim 412 \mathrm{Adc})$ in inverter mode and $136 \mathrm{~kW}(\sim 340 \mathrm{Adc})$ during the battery charging mode.

The SNL battery bank has a $\mathrm{C} / 1$ discharge rate of 655 amperes. Tests requiring currents near or in excess of the $\mathrm{C} / 1$ rate were of limited duration due to rapidly dropping battery voltage.

Battery charge current amplitude is controlled by a potentiometer in the inverter, which sets the de facto generator size. This can cause the inverter to operate as if the generator were much smaller than it really is. The normal setting for a $300 \mathrm{~kW}$ generator was used for this test. The charge power is the difference between the available generator power and the load power. A constant load of $150 \mathrm{~kW}$ should result in $150 \mathrm{~kW}$ of battery charging power from a $300 \mathrm{~kW}$ generator.

In normal operation, the system controller directs the diesel generator to charge the batteries based on the number of amp hours removed from the battery. For the purposes of this test the amp hour counter was disabled and the decision to transfer was based on the battery voltage. The inverter was to begin charging when the battery voltage dropped below $346 \mathrm{Vdc}$, and stop charging when the battery voltage exceeded $428 \mathrm{Vdc}$.

Testing was initiated with a $150 \mathrm{~kW}$ load at 2:00 PM on July 28 . The system began cycling between charge and discharge modes very rapidly. This resulted from the battery bank being small and having a correspondingly large internal resistance. During this portion of the test, the battery was not being either charged or recharged (see Figure 1). Instead the battery voltage jumped to a high value (or low value) almost immediately when charging current was applied (or removed). At 2:30 PM, the test engineer increased the load power to about $180 \mathrm{~kW}$ to reduce the battery charge current and increase the charge/discharge cycle time. The cycles lengthened as charge in the battery was reduced.

A battery heating problem, caused by the high (300 A - 400 A) currents, became apparent by 4:00 PM. At approximately 5:30 PM, the system controller voltage setting was varied to reduce the charging current. Continued heating problems required operator intervention throughout the night. This resulted in less average inverter power than originally desired during the full course of the test (see Figure 2).

At the end of the test, a load of $260 \mathrm{~kW}$ (dc) was drawn by the inverter for a short time (see figure 3). The test was concluded at 9:40 AM on July 29 after running for 20 hours. The inverter performed flawlessly throughout the test. The battery heating problem resulted in our exercising many of the manual and software controls. No problems were noted with the Abacus hardware during this test. 


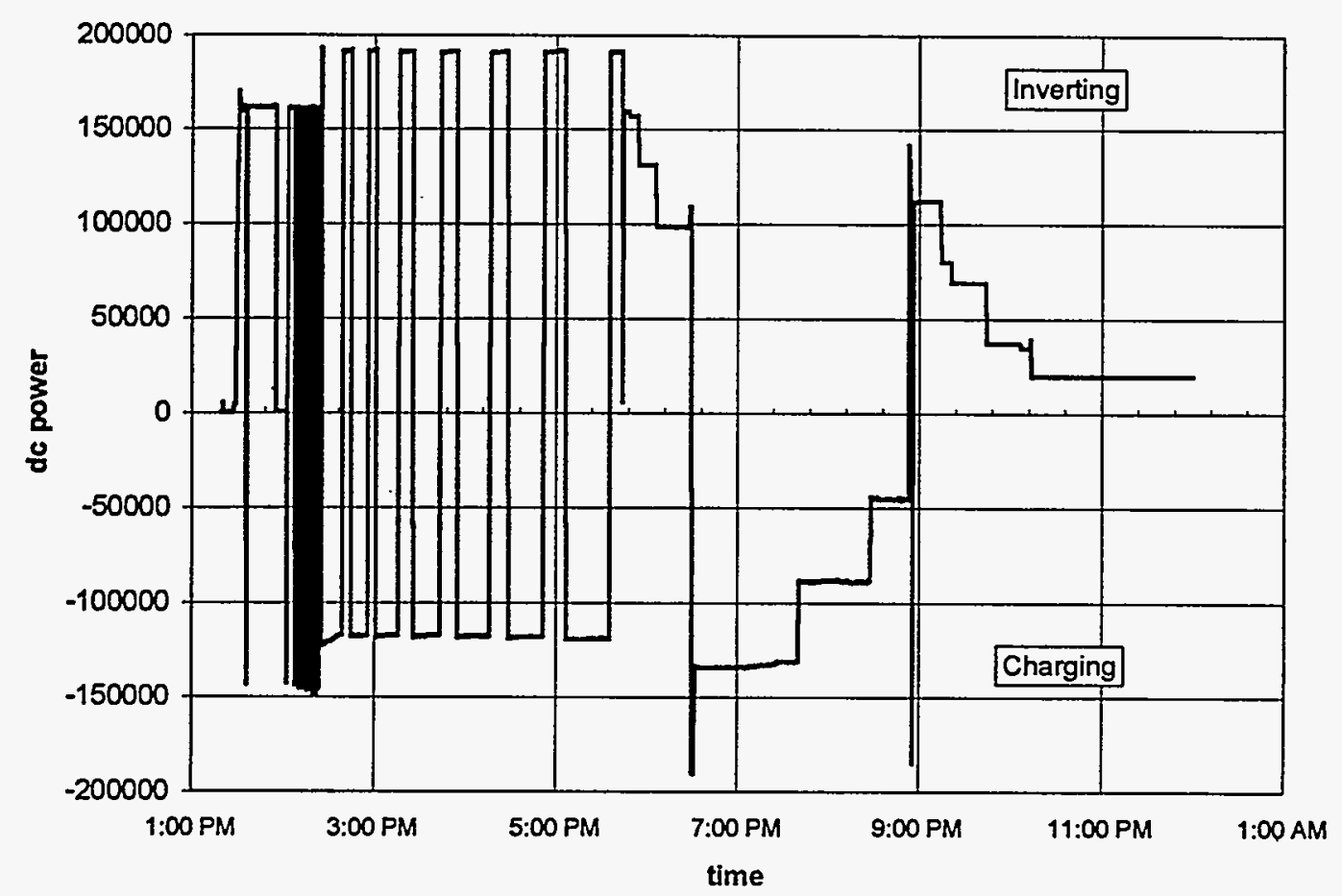

Figure 1: Battery Power for first part of burn-in test

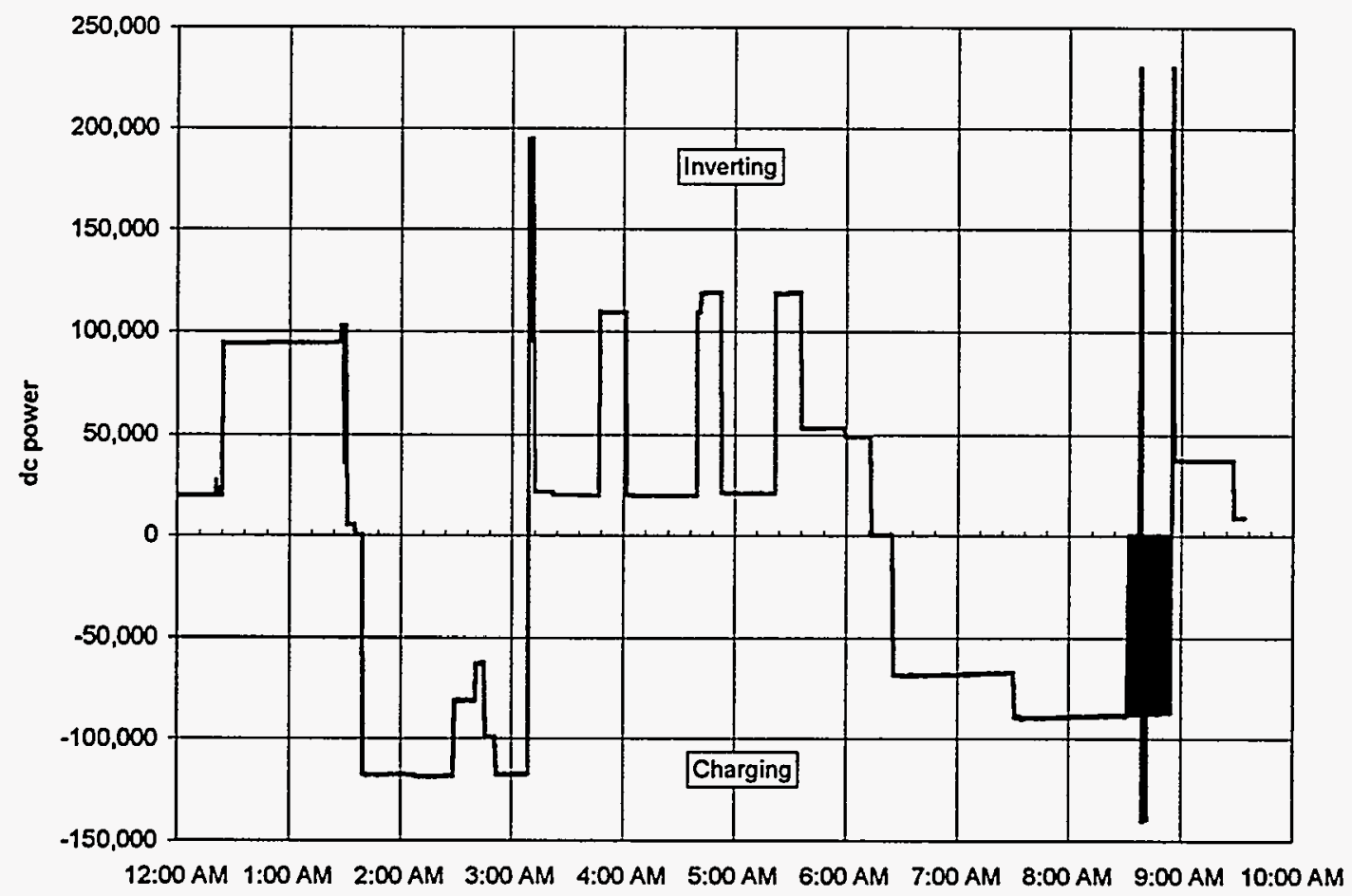

Figure 2: Battery Power for second part of burn-in test 


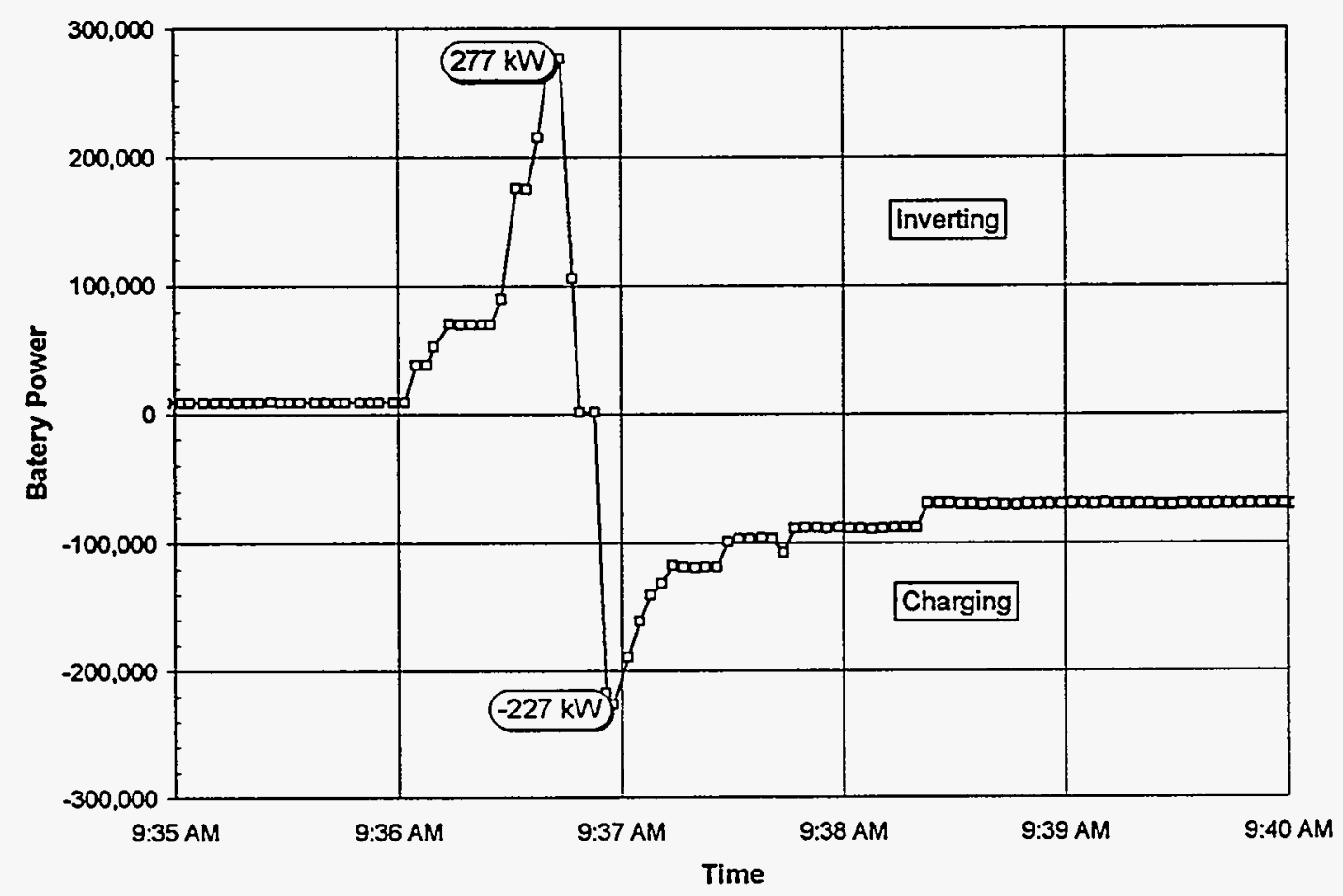

Figure 3: Battery Power for final part of burn-in test

\subsection{System Control}

\subsubsection{Safety}

\subsubsection{Critical Failure Alarm}

"A critical failure is one reducing prime power output or creating a hazardous condition to either personnel or to the photovoltaic system itself. The appropriate programmed system protective shutdown and system disconnects shall be initiated as-soon-as failure is noted". The statement of work is not specific about what items are critical failures; therefore, SNL compiled the list below.

\section{List of Critical Failures}

1. battery string voltage below MDOD

2. battery string over voltage

3. battery cell voltage out of tolerance

4. loss of ac output voltage

5. loss of any MPT

6. detection of ground fault

7. frequency out of spec

8. alarm reset 


\section{Detailed Test Procedures.}

The approach taken to verify the efficacy of the critical alarm system was to create a critical condition or to simulate alarm conditions at the point in the system where the system sensor interfaces to the parameter being monitored.

\section{Detailed Test Results.}

The following critical failure conditions were simulated. In each case, the parameter simulating the failure, the system controller (SC) display, and the status of the alarm output contacts were monitored.

1. Battery string voltage below MDOD. A floating dc power supply was inserted in series with the lead from the highest-voltage end of the battery-nominally, 384 volts. The power supply was configured to subtract from the battery voltage read by the system controller. This voltage was incrementally adjusted, and the SC was then allowed to update its readings at intervals of approximately one minute. Following the update, the simulated battery voltage and the status of the alarm contacts that will be used to initiate an alarm at Superior Valley were recorded. The alarm is programmed to initiate at a battery voltage of 346 volts or less if the generator fails to start. The following values were observed.

\begin{tabular}{|c|c|c|}
\hline $\begin{array}{c}\text { Simulated } \\
\text { Battery } \\
\text { Voltage }\end{array}$ & Alarm Contacts & SC Error Message \\
\hline 361 & Open & None \\
\hline 349.5 & Open & None \\
\hline 346.1 & Open & None \\
\hline 345.5 & Closed & $\begin{array}{c}\text { "Battery MDOD } \\
\text { Approaching. Generator } \\
\text { Not Starting" }\end{array}$ \\
\hline
\end{tabular}

Table 1: Results of MDOD test

2. Battery string over voltage. A floating dc power supply was inserted in series with the lead from the high-voltage end of the battery-nominally, 384 volts. The power supply was configured to add to the battery voltage read by the system controller. This voltage was incrementally adjusted, and the SC was then allowed to update its readings at intervals of approximately one minute. Following the update, the simulated battery voltage and the status of the alarm contacts that will be used to initiate an alarm at Superior Valley, were recorded. The alarm is programmed to initiate at a battery voltage of 500 volts or more. The following values were observed

\begin{tabular}{|c|c|c|}
\hline $\begin{array}{c}\text { Simulated } \\
\text { Battery } \\
\text { Voltage }\end{array}$ & $\begin{array}{c}\text { Alarm } \\
\text { Contacts }\end{array}$ & SC Error Message \\
\hline 471 & Open & None \\
\hline 490 & Open & None \\
\hline 497 & Open & None \\
\hline 501 & Closed & Battery Over Voltage \\
\hline
\end{tabular}

Table 2: Battery over voltage test

3. Battery cell voltage out of tolerance. An out-of-tolerance condition is defined as a deviation of greater than 1.2 volts from the average voltage of the eight strings. A floating 
dc power supply was used to subtract voltage from the highest-voltage end of the battery. The system controller subtracts this voltage (nominally, 384 volts) from that of the nexthighest battery sense lead. The result was the calculated voltage of battery string number eight. This voltage was incrementally adjusted, and the SC was then allowed to update its - readings at intervals of approximately one minute. Following the update, the simulated battery voltage and the status of the alarm contacts that will be used to initiate an alarm at Superior Valley, were recorded. The following values were observed.

\begin{tabular}{|c|c|c|c|c|}
\hline $\begin{array}{c}\text { Simulated Battery } \\
\text { Voltage }\end{array}$ & $\begin{array}{c}\text { Average } \\
\text { Battery } \\
\text { Voltage }\end{array}$ & Deviation & $\begin{array}{c}\text { Alarm } \\
\text { Contacts }\end{array}$ & SC Error Message \\
\hline 49.5 & 48.9 & 0.6 & Open & None \\
\hline 44.3 & 48.3 & 4.0 & Closed & $\begin{array}{c}\text { "Equalization } \\
\text { Required" }\end{array}$ \\
\hline
\end{tabular}

Table 3: Battery cell out-of-tolerance test

\section{Loss of ac output voltage}

The ac voltage sense leads to the SC from bimode unit A1 were removed. The SC displayed a value of zero volts for the phase $A$ ac output voltage. The alarm contacts closed, and the message "Inverter Inoperative-Generator Starting" was displayed.

\section{Loss of any MPT}

An out-of-tolerance array condition is defined as a deviation of greater than $10 \%$ from the average battery charge current of the twelve MPTs. The battery charge current sense signal from the array-driven MPT was connected in parallel to eleven of the SC inputs so that any deviation would be limited to one unit. This unit was powered by the simulator in series with a power supply. The power supply was needed to boost the output voltage from the simulator into the acceptable input window of the MPT. The test was performed in the morning so that the power from the array could be matched by the limited power available from the simulator/power supply combination. At this point, the average current from all twelve channels was $18.09 \mathrm{~A}$. The SC calculated and displayed the allowable lower limit to be $16.28 \mathrm{~A}$. The simulator was adjusted until the output from its MPT was 16 A. After a ten-minute delay time, the alarm contacts closed and the message "Fault on MPT-Array System Operating at Reduced Power" was displayed.

6. Detection of ground fault. A transconductance amplifier was used to inject current into the ground conductor of the battery. This current was monitored by a Hall-effect current sensor, the output of which was fed to the system controller. A similar arrangement will be used at Superior Valley, but with a different current sensor. The following was observed.

\begin{tabular}{|c|c|c|}
\hline $\begin{array}{c}\text { System Controller } \\
\text { Reading (amps) }\end{array}$ & $\begin{array}{c}\text { Alarm } \\
\text { Contacts }\end{array}$ & SCC Error Message \\
\hline 7.3 & Open & None \\
\hline 7.6 & Open & None \\
\hline 9.9 & Open & None \\
\hline 10.0 & Closed & "Excessive Grid Ground Current Condition Present." \\
\hline
\end{tabular}

Table 4: Detection of ground fault

Calibration of the system controller and its associated transducer will be required in the field; however, the alarm functioned correctly. 
7. Frequency out of spec. Successful alarm limits are 59.5 and $60.5 \mathrm{~Hz}$. The inverter frequency was adjusted with an internal potentiometer. The following were observed.

\begin{tabular}{|c|c|l|}
\hline Frequency & Alarm Contacts & SC Error Message \\
\hline 59.96 & Open & None \\
\hline 59.57 & Open & None \\
\hline 59.46 & Closed & $\begin{array}{l}\text { "Bimode Failure Frequency Out of } \\
\text { Tolerance" }\end{array}$ \\
\hline 60.4 & Open & None \\
\hline $60: 6$ & Closed & $\begin{array}{l}\text { "Bimode Failure Frequency Out of } \\
\text { Tolerance" }\end{array}$ \\
\hline
\end{tabular}

Table 5: Frequency deviation test

8. Alarm reset. Following any alarm, the contacts can be opened and the message cleared from the SC display either by manually pressing the alarm reset button or by clicking the "continue" icon on the SC display. Both methods functioned correctly. Following a reset, the condition that caused the alarm must be corrected before the alarm can be reactivated.

\subsubsection{Smoke Alert}

The system shall signal a constant tone "for 5 minutes" if smoke is detected in the PV equipment room. "As soon as the sensed fire condition signal is input to the SC, a transition to diesel power generation will be initiated."

\section{Detailed Test Results.}

Not tested at SNL.

\subsubsection{Monitors and Manual Controls}

\subsubsection{Status Monitors}

"The SC shall continuously monitor the hybrid system performance and indicate its status on a System Status Indicator (SSI)". At a minimum, the SC shall monitor the following performance parameters and for the following fault conditions.

\section{SOW Required Performance Parameters and Detected Fault Conditions}

a) Array source circuits

a.1 Performance --voltage, current, typical module temperature, average current and temperature.

a.2 Faults --extreme current and temperature compared to average.

b) Battery source circuits

b.1 Performance --voltage, current, typical cell temperature of $10 \%$ of all cells.

b.2 Faults --over/under voltage, excessive temperature.

c) PPS status

c.1. Performance --temperature, ac and dc currents (all phases), mode (inverter or rectifier), watt-hours out and in.

c.2 Faults - excessive temperature, current overload.

d) Generator status (all phases) 
d.1 Performance -- on or off, auto or manual control, temperature, currents (all phases), fuel consumption (totaled), engine status (all engine parameters within specifications), watt-hours out.

d.2 Faults -- failure to start, excessive temperature, current overload, engine out of specifications.

e) Grid power (all phases and neutral).

e.1 Performance -- voltages, currents, frequency, watt-hours.

e.2 Faults -- voltages, frequency out of specification.

f) Ground Grid

f.1 Performance -- current to ground.

f.2 Faults -- excessive current to ground.

Detailed Test Results.

The results are listed in Tables 6 and 7 below. Table 6 lists the status items that were observed to work as expected. Table 7 lists those items that were not observed.

\begin{tabular}{|l|l|}
\hline Parameter & \\
\hline \hline Array & Battery \\
\hline array vol & voltage \\
\hline array current & current \\
\hline array average I & typical cell temp \\
\hline array faults & over voltage \\
\hline PPS Status & under voltage \\
\hline mode (inv/rec) & amp-hours in \\
\hline excessive temp & amp-hours out \\
\hline Grid Power & Generator status \\
\hline$\phi A$ voltage & gen on/off \\
\hline$\phi B$ voltage & control auto/man \\
\hline$\phi$ C voltage & gen $\phi$ A current \\
\hline$\phi A$ current & gen $\phi$ B current \\
\hline$\phi B$ current & gen $\phi$ C current \\
\hline$\phi C$ current & watt-hours out \\
\hline$\phi A$ power & Ground Grid \\
\hline$\phi B$ power & current to ground \\
\hline$\phi$ C power & ground fault \\
\hline frequency & \\
\hline voltage out of spec & \\
\hline frequency out of spec & \\
\hline
\end{tabular}

Table 6: Observed status functions 


\begin{tabular}{|l|l|}
\hline Parameter & \\
\hline \hline fuel consumption & Generator Status \\
\hline diesel temperature & over correct \\
\hline array T (typ module) & engine over speed \\
\hline array average mod temp & current overload \\
\hline & low oil pressure \\
\hline & high water temp \\
\hline & overcrank \\
\hline & fault alarm \\
\hline
\end{tabular}

Table 7: Status functions that were not observed

\subsubsection{Manual Controls}

The manual controls are supposed to be foolproof; the SOW states "any sequence of manual operations cannot cause damage." The manual controls perform the following functions:

a) Disable automatic generator control.

a.1 Start/stop generator.

a.2 Transfer load between the power processing system (PPS) and generator (switch PPS between inverter and rectifier modes).

b) Initiate battery charge cycle.

c) Initiate battery equalization.

d) Adjust ODOD.

e) Alarm reset to inhibit audio alarm.

f) Emergency shut-down.

Detailed Test Results.

The manual controls on the system controller were adjusted in many different ways during the course of the test. The current configuration of the system controller appears to be immune to damage by improper setting of a switch position. Manual switches on the inverter, such as the dc breaker, cannot be indiscriminately changed.

\subsubsection{Battery Health and Maintenance}

\subsubsection{Battery Charging Cycle}

"The system controller shall initiate a battery charge cycle whenever the battery reaches the preset operational depth-of-discharge (ODOD). The ODOD shall not exceed $70 \%$." The batteries are to be charged to $90 \%$ SOC on a daily basis (except Sunday). The equalization charge (on Sunday night) will charge the batteries to a higher SOC than the daily charge.

The charge algorithm used by Abacus keys off both battery voltage and amp-hours. In addition, there are firmware settings inside the inverter that disconnect the battery from the inverter if the battery voltage reaches 336 volts. On a. daily basis, when the battery reaches ODOD (adjustable in the software), the battery charger replaces the amp-hours that have been removed from the battery up to $90 \%$ SOC. 
This entire scheme of charging assumes that the batteries are fully charged at the beginning of the sequence. It is important in field operation that the batteries be equalized prior to beginning the weekly sequence.

The dc ripple is specified to be $<2 \%$ for all conditions. The dc wave-shape was - recorded and the peak-to-peak ripple was noted while at various points in the charge cycle.

\section{Test Configuration.}

$$
\begin{aligned}
& \text { PV power = disconnected } \\
& \text { simulator = off } \\
& \text { loads = as required. } \\
& \text { diesel = off (inverter forced on) } \\
& \text { battery = initial battery SOC = fully charged }
\end{aligned}
$$

\section{Detailed Test Results.}

This test exercises the system controller ability to sense ODOD, turn on the generator, charge the batteries, and then stop the generator. To accomplish this, the amp-hour counter for the system controller was set to an artificial number. The following sequence of events was observed.

1. With the ODOD set at $85 \%$, the inverter started the generator at $84 \%$.

2. After a time delay for generator warm-up, the system transferred to generator.

3. After a 15 second delay, the charging began.

4. The inverter stopped charging when the battery SOC was $88 \%$.

5. After a short delay, the controller turned off the generator.

Although the SOC did not return to $90 \%$ as desired, the proper sequence of events was observed. Due to differences in the battery bank, the algorithm parameter values must be adjusted in the field during system operation.

The ripple on the dc charge voltage was less than $1 \%$.

\subsubsection{Battery Equalization Schedule}

"The SC shall initiate a battery charge equalization schedule according to the battery manufacturer's specifications." On a weekly basis, or when manually requested, the system controller will equalize the battery by charging the batteries until the amp-hour counter is returned to zero plus $8 \%$. The amp-hour counter is then reset to zero.

\section{Detailed Test Results}

The amp-hour counter was manually adjusted so that the equalization cycle could be evaluated. The following sequence of events was observed.

1. The equalization cycle was requested manually.

2. After a time delay for generator warm-up, the system transferred to generator.

3. After a 15 second delay, the charging began. The inverter stopped charging when the battery amp-hour count equaled the initial amp-hour count plus $8 \%$.

4. The amp-hour counter was reset to zero.

5. After a short delay the controller turned off the generator. 
The equalization cycle was successful. Of course, if a number other than $8 \%$ is desired at Superior Valley; it can be adjusted in situ.

\subsubsection{Full Generator Utilization}

The system is supposed to fully load the diesel generator, when possible. Full generator utilization was evaluated in several portions of the test program.

\section{Detailed Test Results}

Full generator utilization is demonstrated in Figure 4 below. In this test, the total load power was adjusted in steps from 3,400 watts to $147 \mathrm{~kW}$. The charge power was automatically adjusted by the bimode so that the generator output power was constant at approximately $297 \mathrm{~kW}$. When the charging was stopped, the generator output dropped to the load power plus some housekeeping power losses.

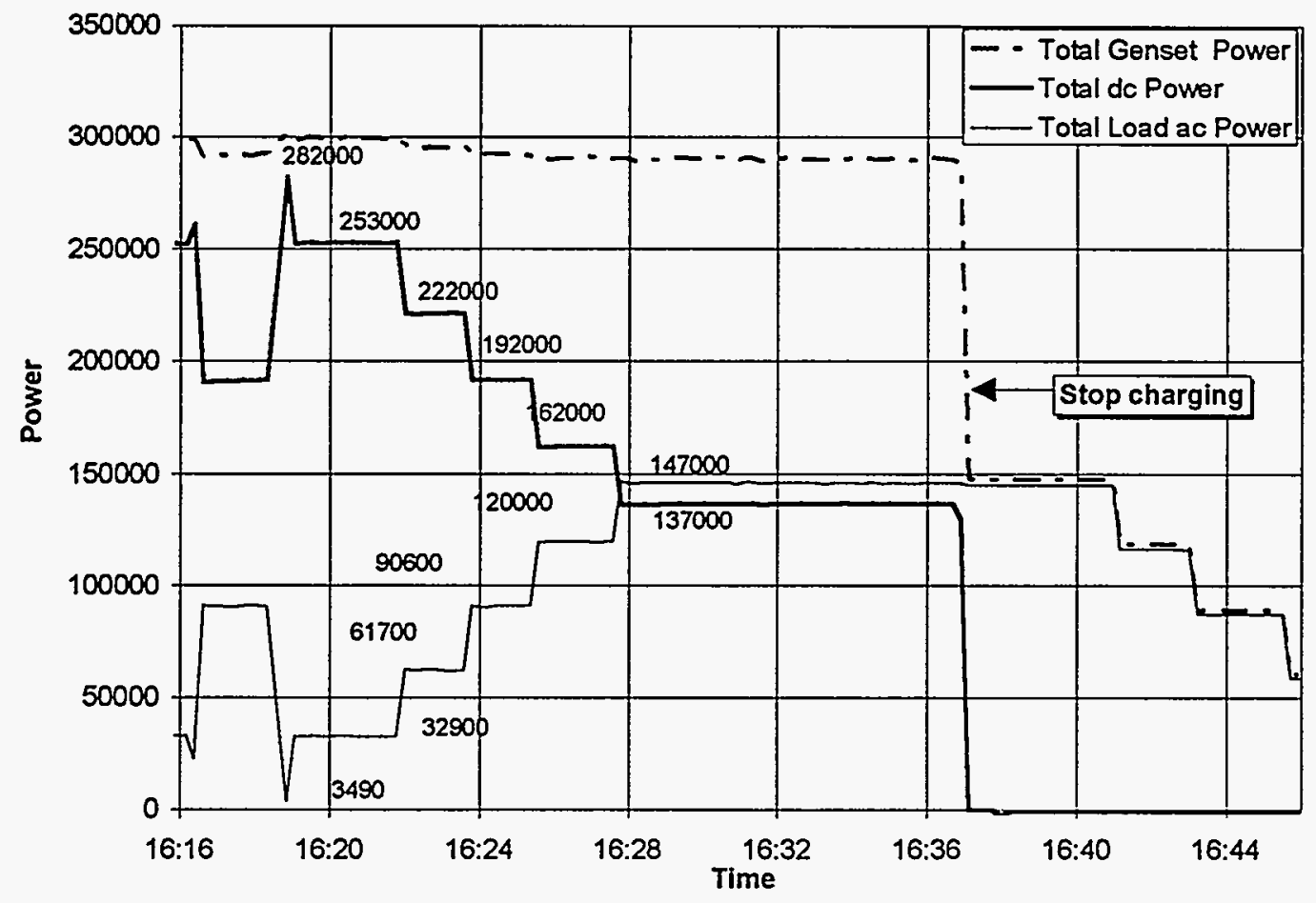

Figure 4: Example of full utilization of the generator

\subsubsection{Protection from battery over discharge}

"The SC shall prevent the battery from reaching a DOD greater than the maximum DOD." The fail-safe protection for the battery is performed by the inverter, not the SC. The inverter will shut down if the battery voltage is less than $336 \mathrm{Vdc}$. This value is set in the firmware inside the inverter ASIC.

\section{Detailed Test Results}

While powering a constant load of $60 \mathrm{~kW}$, the inverter did shut down when the battery voltage reached $332 \mathrm{Vdc}$. This is slightly lower than the anticipated value of $336 \mathrm{Vdc}$. 


\subsection{Inverter Power Quality and Performance}

\subsubsection{Rated Power}

The specified rated power is $100 \mathrm{kVA}$ continuous/phase. Because of the limited battery capacity at SNL, only one phase was fully loaded at a time for most of the tests. Since the Abacus design separates each phase, this approach did fully exercise the inverters. During this portion of the test, a'number of additional parameters were monitored. These include inverter efficiency, ac distortion, voltage regulation, phase-to-phase balance, and frequency regulation. Related specifications are

1. total harmonic voltage distortion (THD) $\leq 5 \%$

2. individual harmonic distortion $\leq 3 \%$

3. ac voltage regulation is $\pm 5 \%$ Vac

The frequency stability and phase-to-phase balance are not specified. It is noted; however, that a phase-to-phase unbalance of $3 \%$ will cause a rise in the temperature ${ }^{2}$ of a three phase motor of $25 \%$.

Measurements were made before, after, and during load transients. These load conditions included

- transfer from $8.6 \mathrm{~kW} / \mathrm{phase}$ to $110 \mathrm{~kW}$ on phase $\mathrm{A}$

- transfer from $89 \mathrm{~kW} / \mathrm{phase}$ to $106 \mathrm{~kW}$ on phase $A$

- transfer from $27 \mathrm{~kW} / \mathrm{ph}$ ase to $90 \mathrm{kVA}$ on phase A reactive load with $8 \mathrm{PF}$.

- transfer from $150 \mathrm{~kW}$ to $314 \mathrm{~kW}$.

in this test total distortion is recorded rather than total harmonic distortion.

\section{Test Configuration.}

$$
\begin{aligned}
& \text { PV power = on } \\
& \text { simulator = off } \\
& \text { loads = variable } \\
& \text { diesel = off (inverter forced on) } \\
& \text { battery SOC = nominal }
\end{aligned}
$$

\section{Detailed Test Results.}

Steady-state measurements across load transitions. The steady-state values were recorded just prior to and just after load transitions. These measurements are shown in Table 8. The phase A inverter was loaded to $110 \mathrm{~kW}, 10 \%$ more than the steady-state rated value. The maximum frequency variation across the load step was $.1 \mathrm{~Hz}$. The largest observed value of total distortion was $2.45 \%$. The worst case value for voltage regulation was $2.6 \%$. At no time during this test did the inverter fail to meet its design specification.

Transient response. Figure 5 shows the transient response due to the application of a step load that increased the phase $A$ loading from $10 \mathrm{~kW}$ to $90 \mathrm{~kW}$. Loads on phases $B$ and $C$ remained $10 \mathrm{~kW}$ each. The notch in the inverter output voltage (at .04 seconds on the trace) is $17 \%$ of the peak voltage and 1 millisecond wide. Depending on the timing of the load application, this notch could cause an additional zero crossing of the voltage.

2. Energy Management Handbook, Wayne C. Turner Fairmont Press, Inc. 1993. 


\begin{tabular}{|c|c|c|c|c|c|c|c|c|c|}
\hline & $V_{\text {bat }}$ & $\begin{array}{l}\% \text { Vdc } \\
\text { change }\end{array}$ & $\begin{array}{l}\text { phase A } \\
\text { voltage }\end{array}$ & $\begin{array}{l}\text { \% change in } \\
\text { phase A } \\
\text { voltage }\end{array}$ & VA & $\mathrm{pf}_{\mathrm{A}}$ & $\begin{array}{l}\text { AC Freq } \\
\mathrm{Hz}\end{array}$ & $\begin{array}{l}\Delta \text { freq } \\
\mathrm{Hz}\end{array}$ & $\begin{array}{l}\% \text { ACV } \\
\text { Dist. }\end{array}$ \\
\hline \multicolumn{10}{|c|}{ Load ON transition (8.6k to 110k), Resistive Loads, Nominal Battery Voltage } \\
\hline before & 382. & & 238.1 & & $8.6 \mathrm{k}$ & 1 & 59.9 & & 1.53 \\
\hline after & 358. & $6.3 \%$ & 240.8 & $1.1 \%$ & $110 \mathrm{k}$ & 1 & 60.0 & .1 & 2.45 \\
\hline \multicolumn{10}{|c|}{ Load decrease transition (105k to 29k), Resistive Loads, Nominal Battery Voltage } \\
\hline before & 357 & & 241.2 & & $106 \mathrm{k}$ & 1 & 59.9 & & 2.43 \\
\hline after & 374 & $4.6 \%$ & 238.3 & $1.2 \%$ & $29 k$ & 1 & 59.9 & 0 & 1.67 \\
\hline \multicolumn{10}{|c|}{ Load ON transition, Reactive Load (27kW to $90 \mathrm{kVA}$ ), Nominal Battery Voltage } \\
\hline before & 374 & & 238.0 & & $27 \mathrm{~kW}$ & 1 & 59.9 & & 1.82 \\
\hline after & 364 & $2.7 \%$ & 232.4 & $2.6 \%$ & $90 \mathrm{kVA}$ & .8 & 59.9 & 0 & 2.33 \\
\hline \multicolumn{10}{|c|}{ Toad Increase transition, Resistive Loads (89k to 106k), Nominal Battery Voltage } \\
\hline before & 361.9 & & 240.4 & & $89 \mathrm{k}$ & 1 & 59.9 & & 2.25 \\
\hline after & 357.2 & $1.3 \%$ & 241.1 & $.3 \%$ & $106 \mathrm{k}$ & 1 & 59.9 & 0 & 2.41 \\
\hline
\end{tabular}

Table 8: Steady-state measurements across load transitions

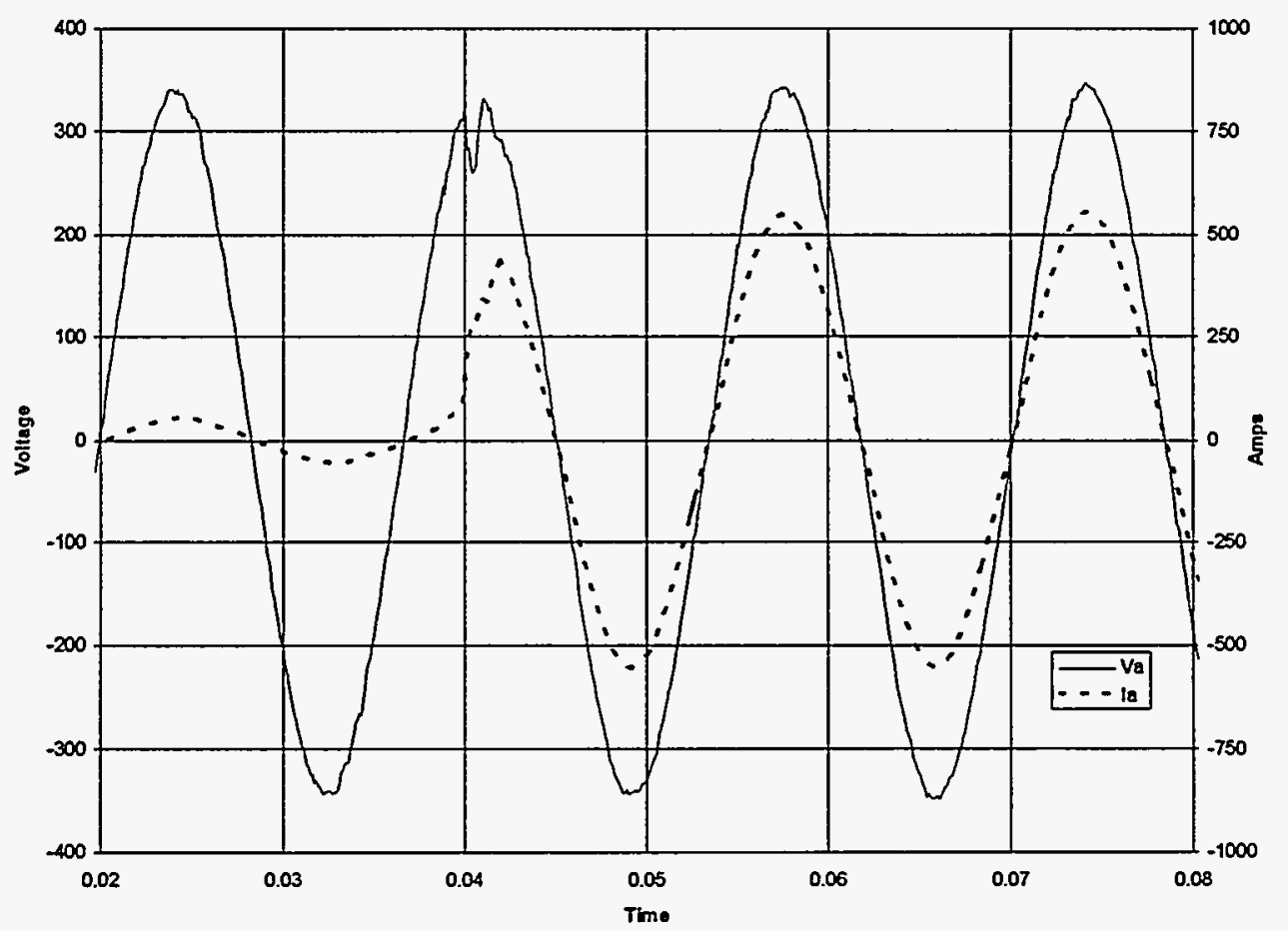

Figure 5: Transient response for $10 \mathrm{~kW}$ to $90 \mathrm{~kW}$ load step

Figure 6 shows the transient response due to application of a step load that increased the phase A load from $27 \mathrm{~kW}$ to $90 \mathrm{kVA}, .8 \mathrm{PF}$. Loads on phases $\mathrm{B}$ and $\mathrm{C}$ remained $27 \mathrm{~kW}$ each. There is not a significant voltage transient during the transition. There is a 16 volt sag in the peak voltage at time $0.12 \mathrm{sec}$; however, the voltage recovers quickly. The current takes about 1.5 cycles to reach its peak value of 627 amperes at 0.9 seconds. This is 76 amps over the steady-state current value of 551 amps. This current overshoot has not been observed in tests of other (lower power) inverters using the same load. 


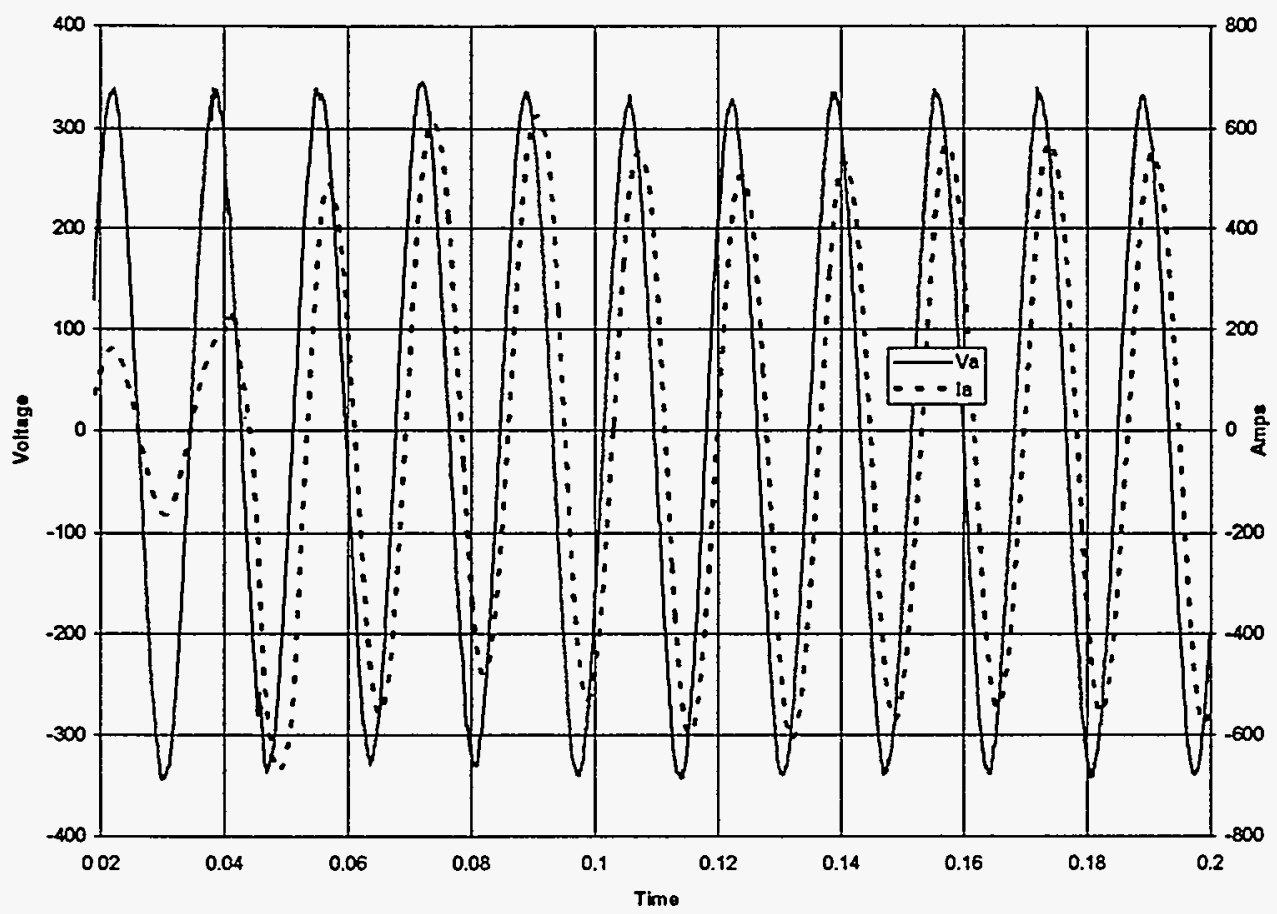

Figure 6: Step load response for $27 \mathrm{~kW} /$ phase to $90 \mathrm{kVA}, .8 \mathrm{PF}$, Phase $\mathrm{A}$

Phase imbalance. The effect of unbalanced loading on voltage regulation can be observed in Figures 7 and 8 . Figure 7 shows that placing an inductive load on a single phase causes a significant voltage imbalance among phases. Starting with approximately $20 \mathrm{~kW}$ on each phase, the resistive and inductive loads on phase $A$ were varied, resulting in $86 \mathrm{kVA}$ at a power factor of 0.74 . At this point, the phase $A$ voltage dropped from 239.5 $\mathrm{Vac}$ to $231 \mathrm{Vac}$, and the voltages of phases $\mathrm{A}$ and $\mathrm{B}$ were 8 volts apart. This represents a voltage regulation on phase $A$ of $3.5 \%$ and a phase imbalance of $3.3 \%$.

A large imbalance in a purely resistive load does not produce such a voltage imbalance. When the load on one phase was increased from $10 \mathrm{~kW}$ to $110 \mathrm{~kW}$ with $10 \mathrm{~kW}$ remaining on each of the other two phases (Figure 8 ), the resulting voltage imbalance was less than $1 \%$.

It is observed that applying a balanced load (Figure 9) with a power factor of .72 reduces the inverter output voltages in a balanced manner. The sequence of events is

\begin{tabular}{l|l||l|l} 
time & event & time & event \\
\hline start & generator running, no load & $2: 10: 25$ & load increased to 198 kVA \\
2:04:17 & $150 \mathrm{~kW}$ resistive load applied & $2: 11: 16$ & all loads removed \\
2:05:11 & all loads removed & $2: 14: 48$ & step load of 198 kVA \\
2:05:30 & generator turns off & $2: 15: 40$ & all loads removed \\
2:09:58 & $150 \mathrm{~kW}$ resistive load applied & &
\end{tabular}

Note that the maximum recorded phase-to-phase voltage imbalance of 1.6 volts, (at time $2: 15$ ) corresponds to a $.7 \%$ imbalance. The maximum change in inverter output voltage occurs when the generator shuts off; at that point, the inverter output voltage changes from $248 \mathrm{Vac}$ (the generator voltage plus 9 volts) to $240 \mathrm{Vac}$. Under resistive 


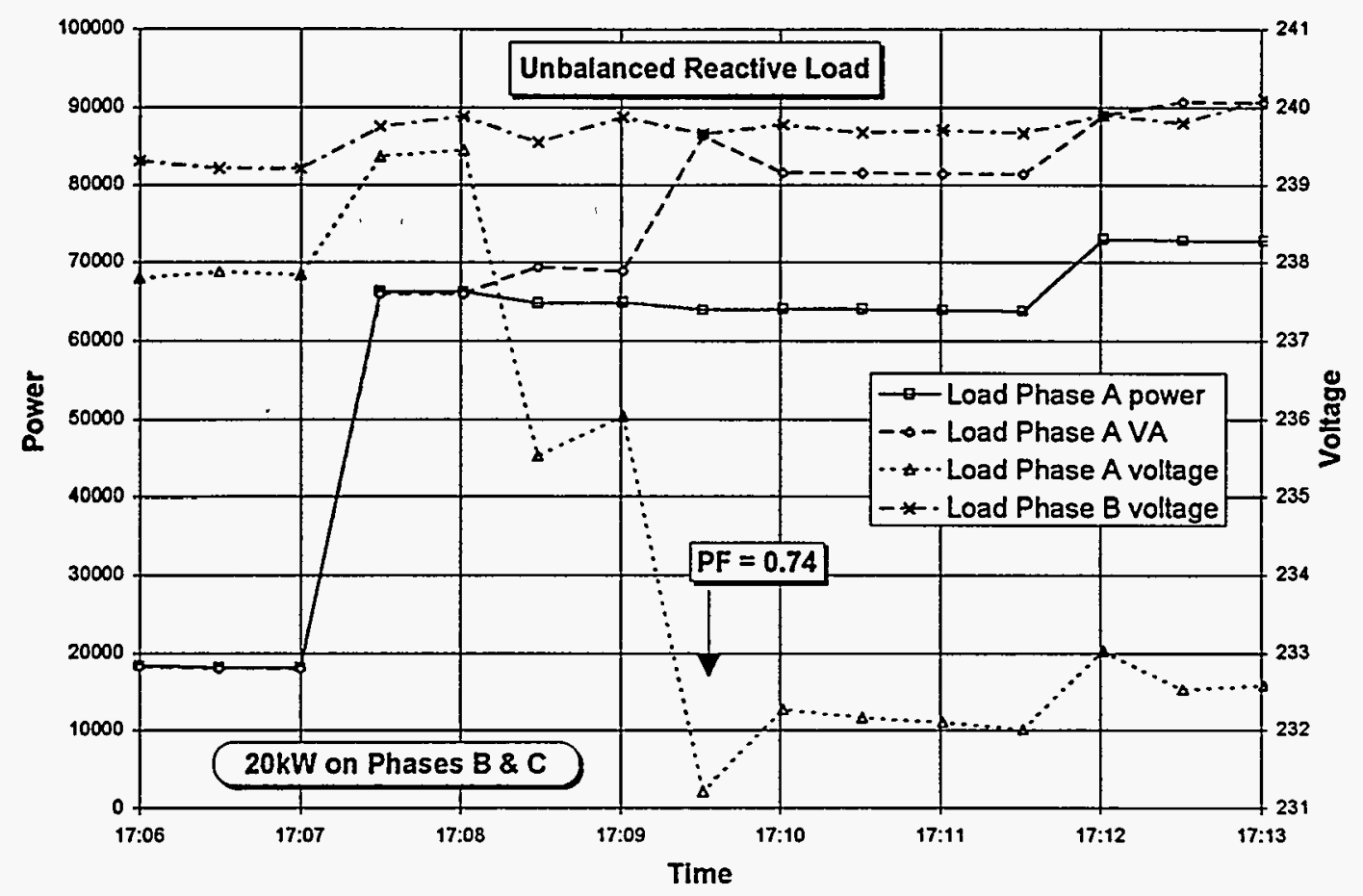

Figure 7: Voltage regulation and phase-to-phase imbalance

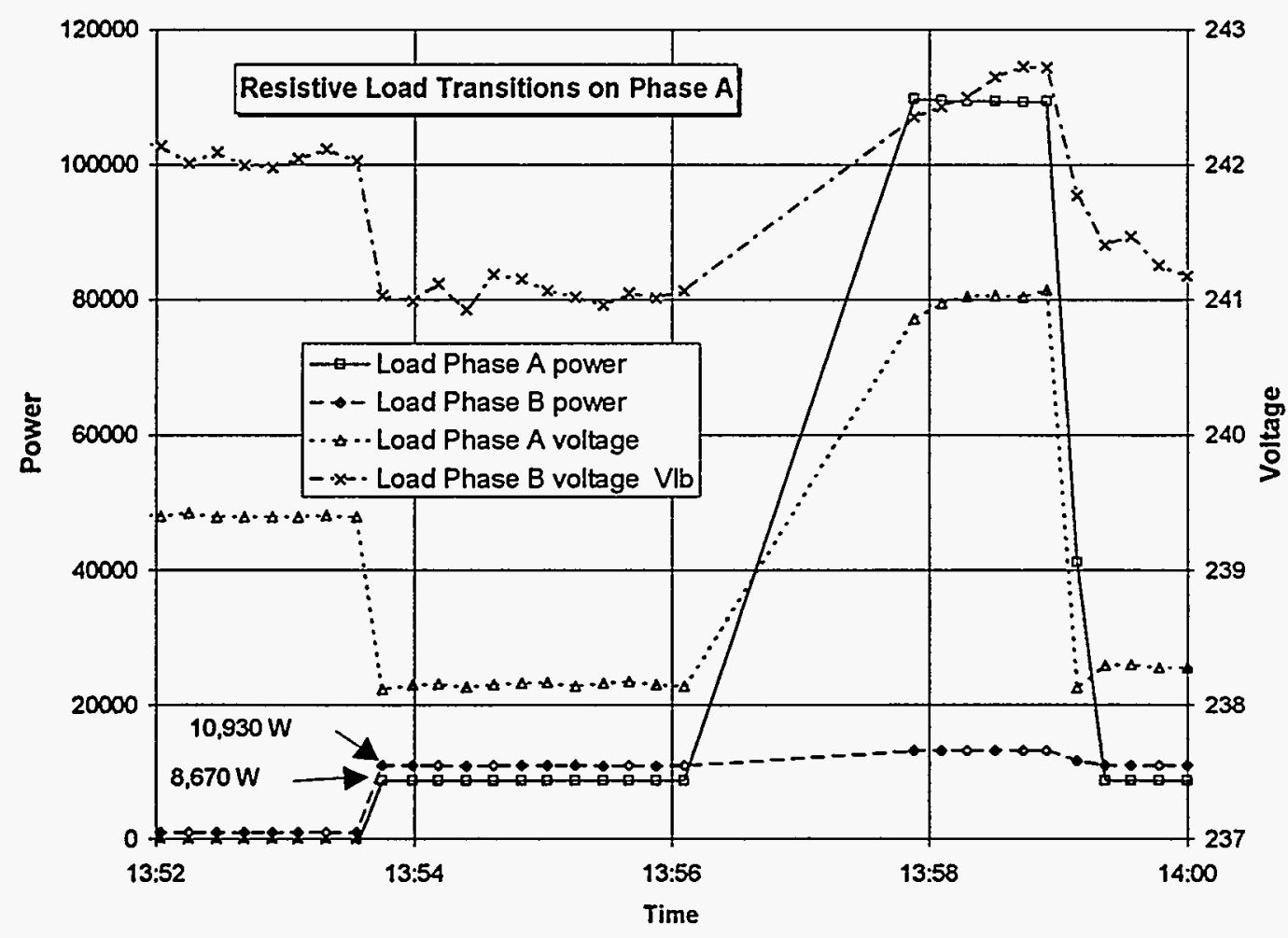

Figure 8: Phase voltages with unbalanced resistive load 


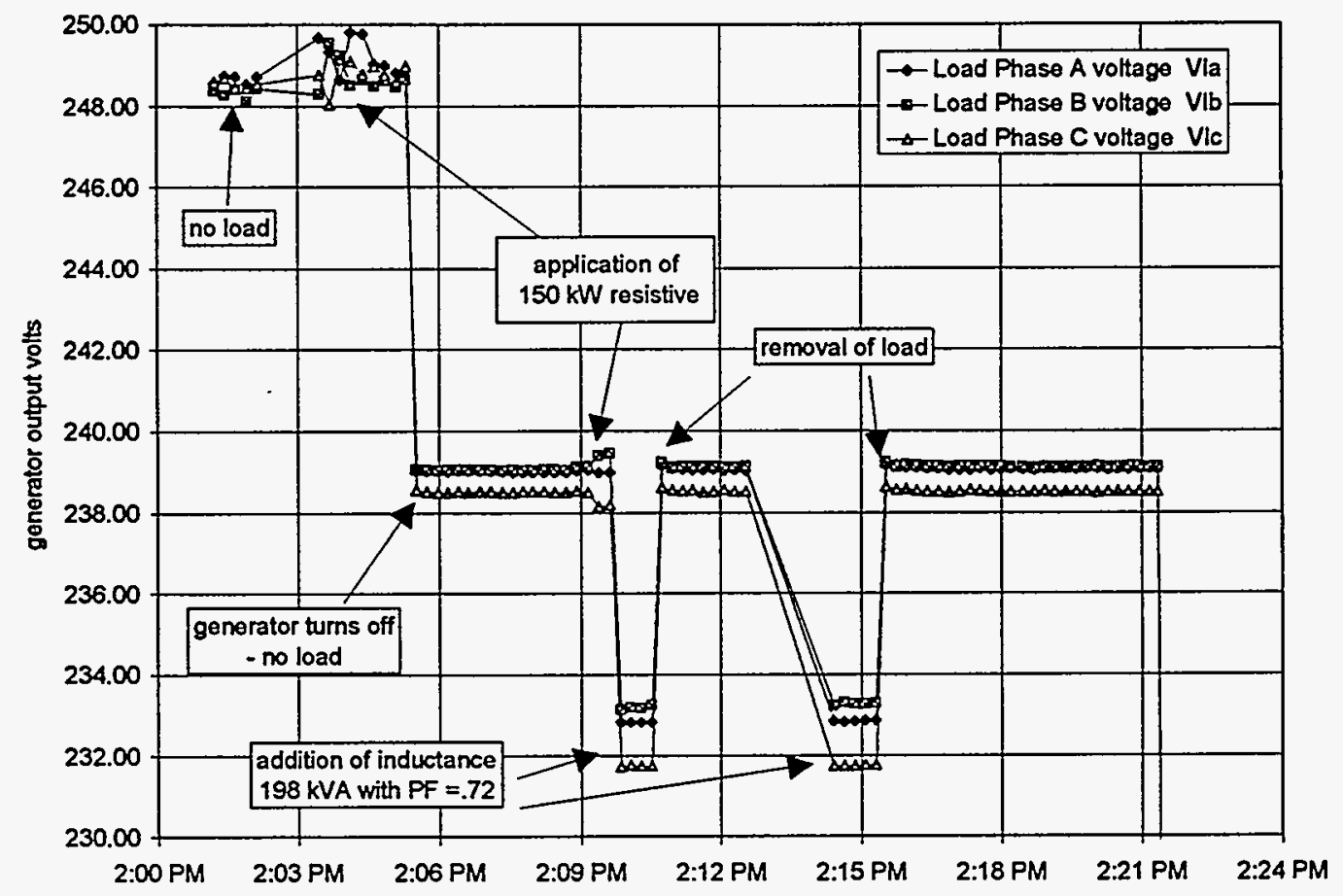

Figure 9: Phase voltages for a balanced $198 \mathrm{kVA}, .72 \mathrm{PF}$

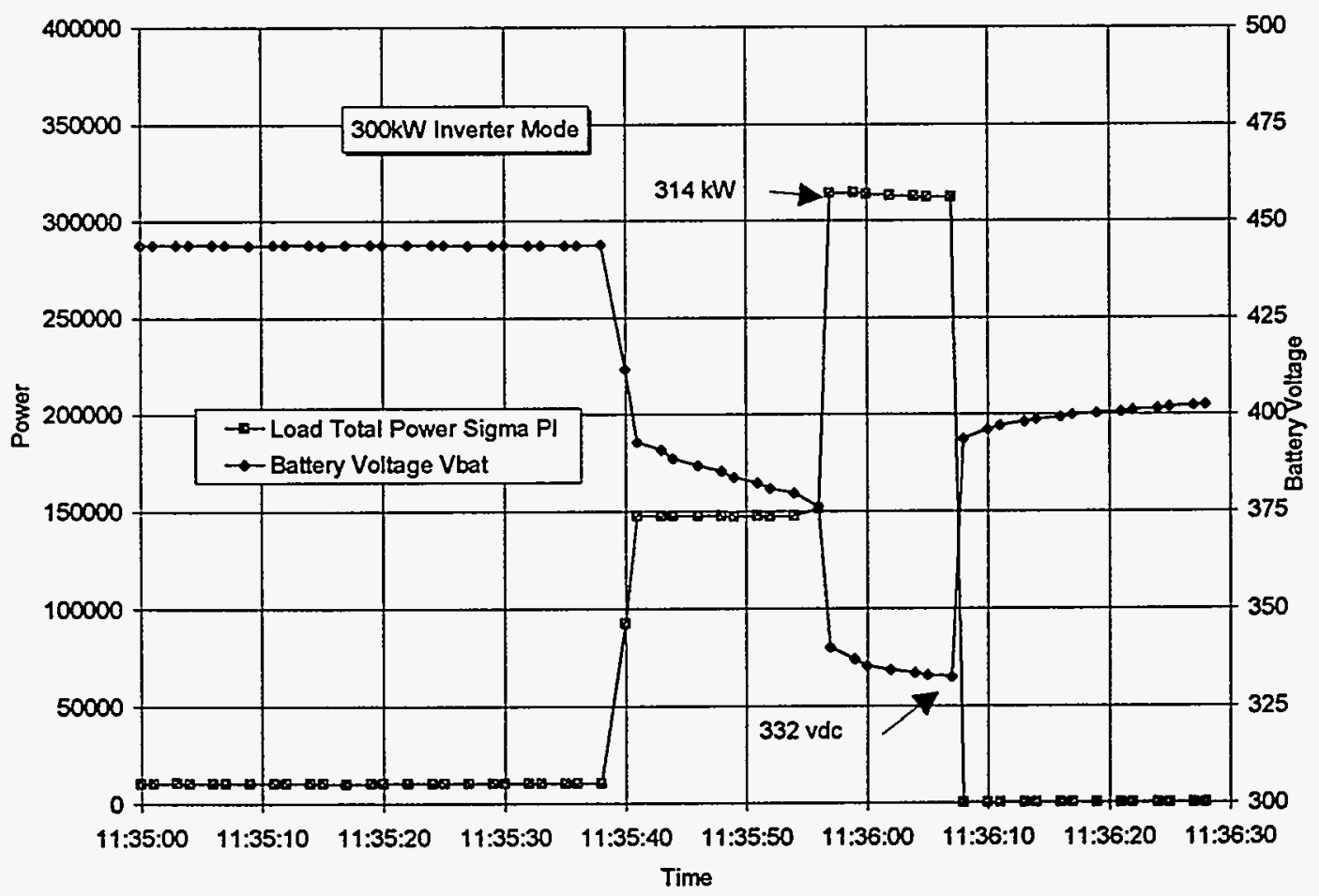

Figure 10: Inverter loading at $314 \mathrm{~kW}$

load, the voltage regulation is seen to be very good. When reactive loads are applied, the voltage drops from $239 \mathrm{Vac}$ to $233, \mathrm{Vac}$, a change of less than $3 \%$. It is interesting to note that the inverter voltage stability is better than the generator voltage stability.

After battery equalization, the inverter was run at full rated power for a short time (Figure 10). The test did verify that the inverter was capable of handling $314 \mathrm{~kW}$ of power. 
When the $314 \mathrm{~kW}$ load was connected to the inverter, the battery voltage dropped to 337 $\mathrm{Vdc}$ and dropped further to $332 \mathrm{Vdc}$ after about 10 seconds of operation. Since that value of dc voltage would have initiated a shutdown by the system controller, the load was then disconnected.

\subsubsection{Efficiency}

\subsubsection{Inverter Efficiency}

This test evaluated the efficiency of converting dc energy to ac energy. The inverter efficiency was evaluated using a stepped resistive load from no-load to full load at nominal battery voltage.

\section{Test Configuration.}

$$
\begin{aligned}
& \text { PV power = disconnected } \\
& \text { loads = as specified } \\
& \text { diesel = off, inverter forced on } \\
& \text { battery SOC nominal }
\end{aligned}
$$

\section{Detailed Test Results.}

The inverter output power and the inverter input power for all three phases were evaluated (see Figure 11). The input power was evaluated by measuring the input voltage and current. Note that the dc battery voltage is also displayed. The maximum efficiency is $93.5 \%$ at $246 \mathrm{~kW}$.

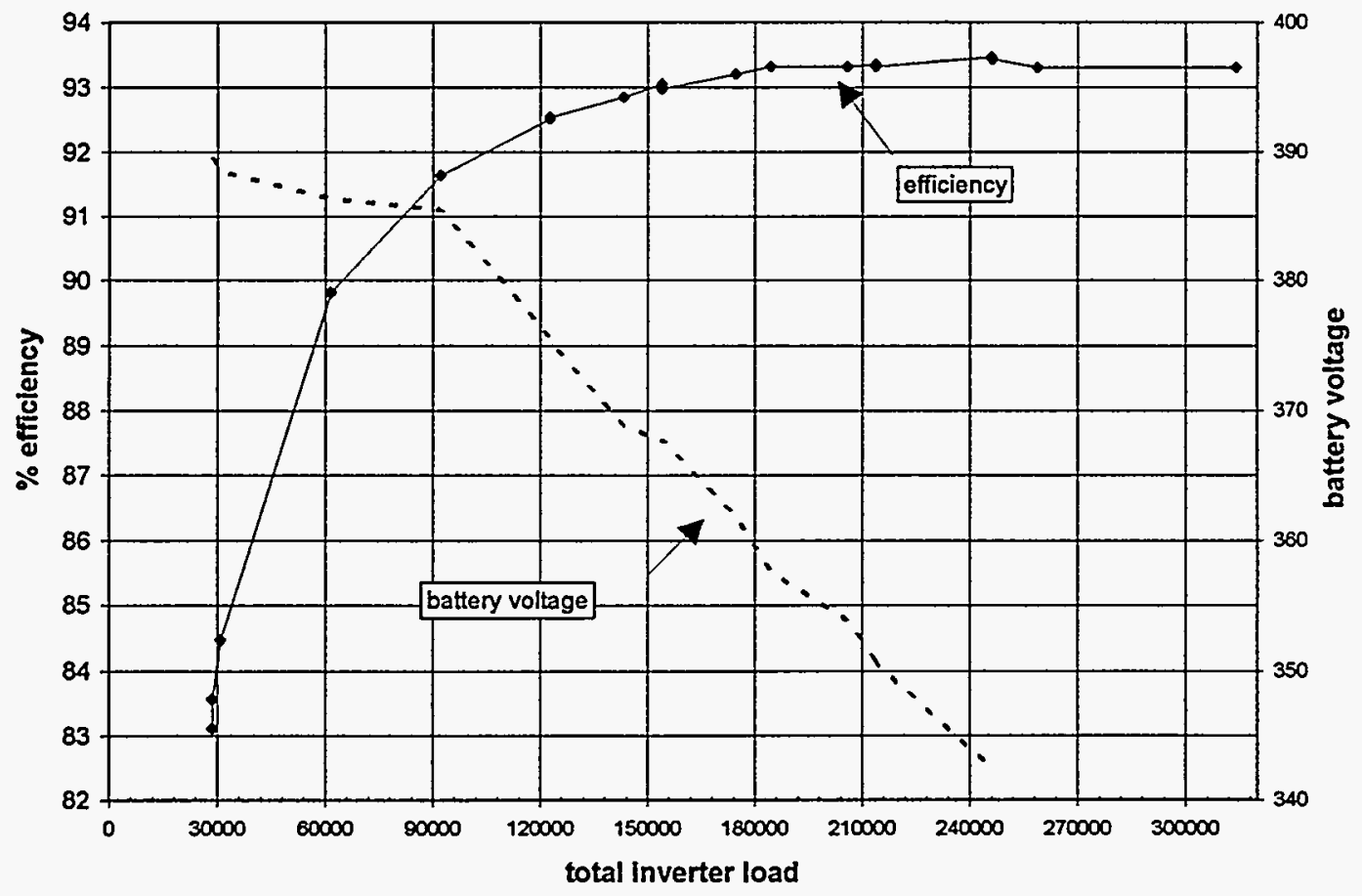

Figure 11: Inverter efficiency with resistive loading 


\subsubsection{Charge Mode Efficiency/Charge Power}

To evaluate the relationship between battery voltage and charger efficiency, the power into the inverter (from the diesel) and out of the inverter (to the batteries) was monitored for a complete charging cycle, nominally $346 \mathrm{Vdc}$ to $442 \mathrm{Vdc}$.

Test Configuration.

PV power $=$ disconnected

diesel $=$ on

loads $=$ disconnected

battery SOC = discharged to MDOD (maximum depth of discharge) for start of test

\section{Detailed Test Results.}

Charge Efficiency. The charge efficiency was measured over a dc charging power range of $136 \mathrm{~kW}$ to $282 \mathrm{~kW}$. The efficiency was $95 \pm .5 \%$ over the entire range. The efficiency was independent of the charging power.

Maximum Measured Charge Power. The generator was loaded up to $302 \mathrm{~kW}$ with 282 $\mathrm{kW}$ of dc charge power and $3.5 \mathrm{~kW}$ of ac load power. At this power, the efficiency was $94.6 \%$

\subsubsection{Transfer of Sources}

"The PPS and generator shall remain phase locked while the generator is connected to the ac bus under normal operations. The mode switch/load transfer shall be synchronous and free of any transient that may stress or damage the power system or site loads."

\section{Detailed Test Results.}

The transfer from generator to inverter (Figure 12) is identified by the cessation

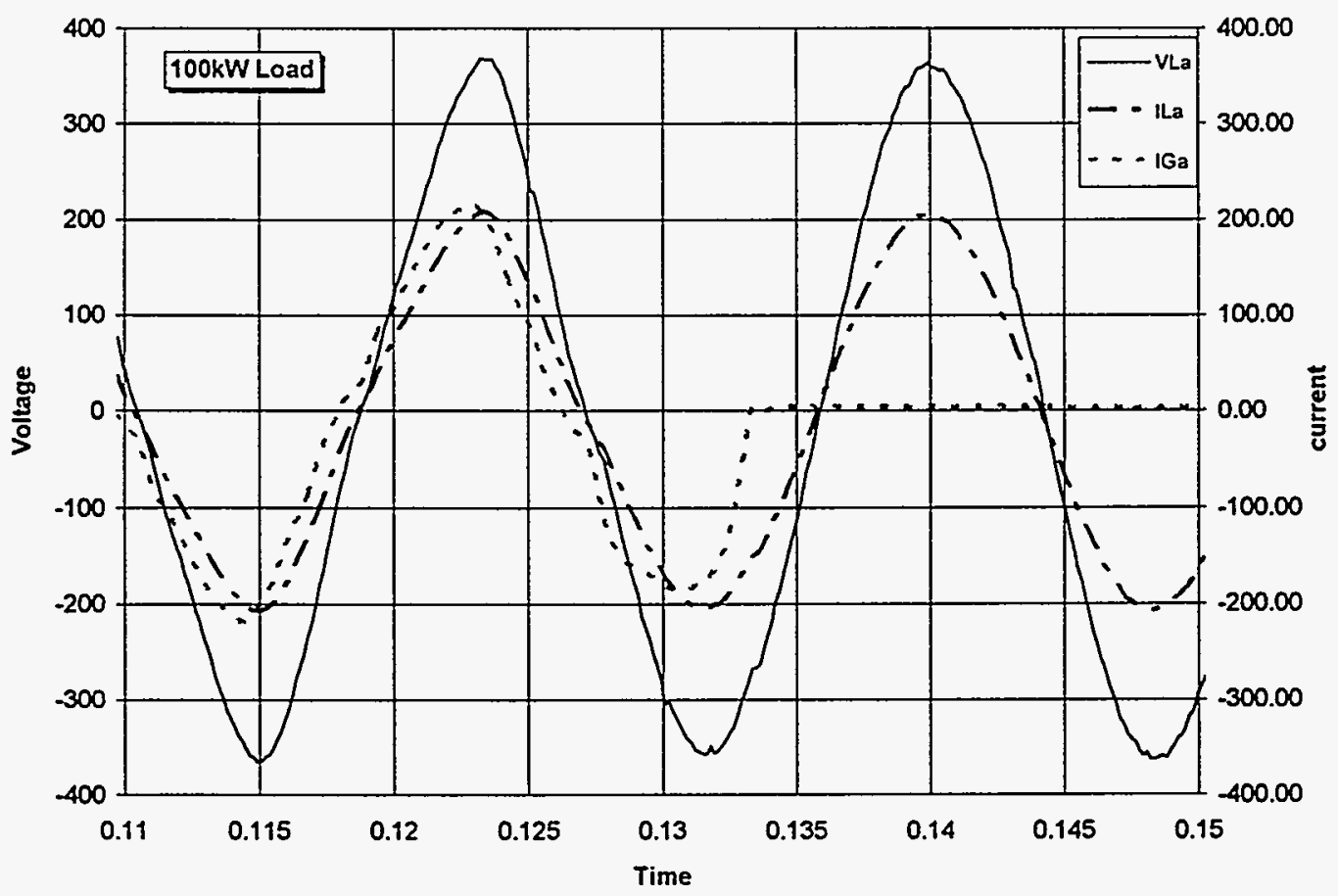

Figure 12: Transfer from generator to inverter with $100 \mathrm{~kW}$ load 
of generator current at .133 seconds into the trace. The transient distortion on the voltage waveform is small. The load was $100 \mathrm{~kW}$ during this test.

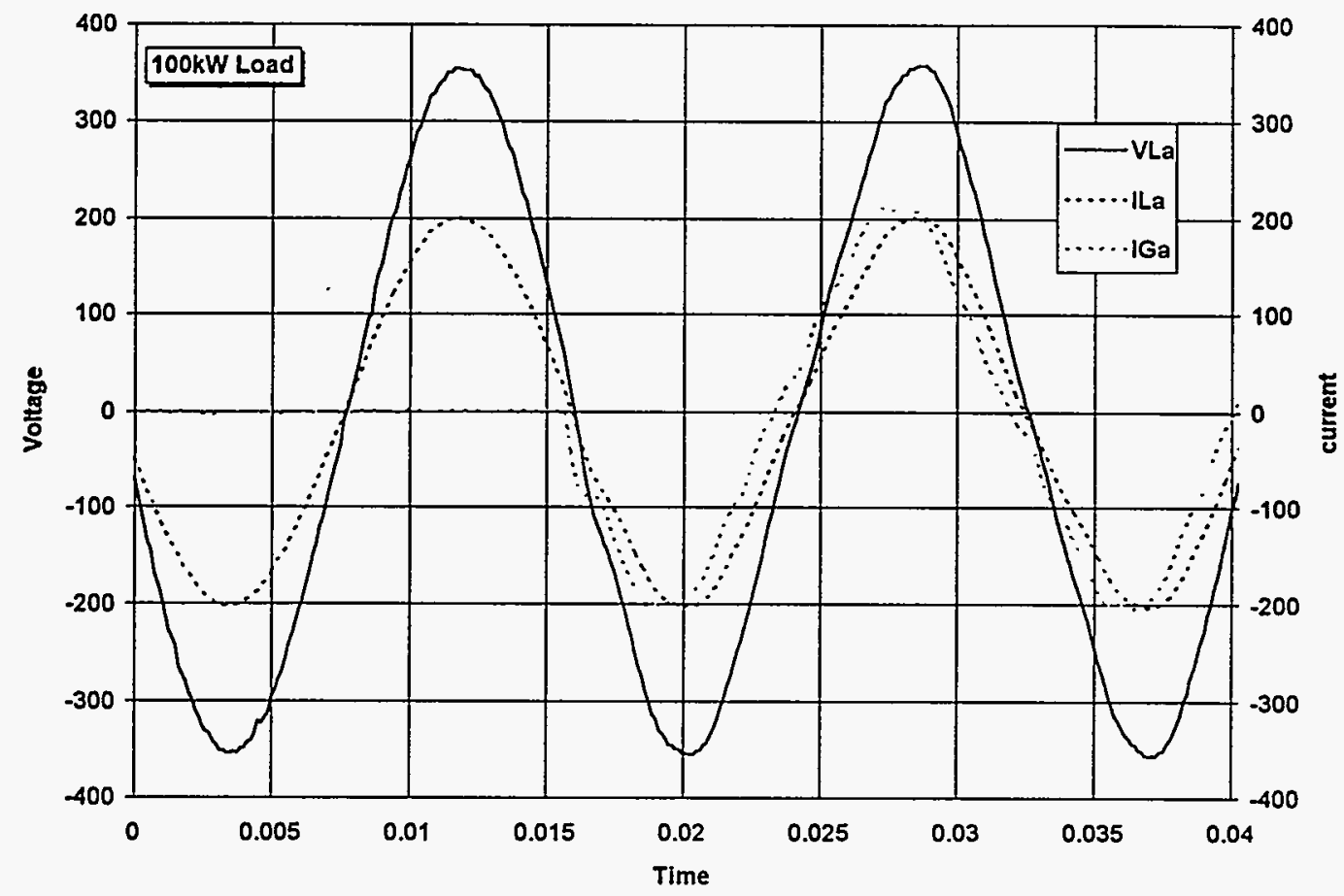

Figure 13: Transfer from Inverter to Generator with $100 \mathrm{~kW}$ load

The transfer from inverter to generator occurs at .015 seconds into the trace shown in Figure 13. The transfer occurs during a voltage zero crossing, after the generator is warmed up and the inverter has synchronized with the generator. The load was $100 \mathrm{~kW}$ during this test.

Finally, the initiation of charge current is displayed in Figure 14. This initiation occurs 15 seconds after the inverter has transferred from inverter to generator. Loading the generator with $150 \mathrm{~kW}$ of load, plus $150 \mathrm{~kW}$ of charging power, results in a "fully loaded" generator load of $300 \mathrm{~kW}$. The additional distortion on the top of the voltage waveform during the charge mode is small and should not interfere with equipment operation.

\subsubsection{Reactive/Nonlinear Loading}

The nonlinear loads were provided by a full wave bridge rectifier. The distortion measurements included both THD and TD so that the distortion of individual harmonics can be evaluated. The specification required that the THD be no greater than $5 \%$ with the following loads:

1. $60 / 55 / 45 \mathrm{~kW}, .7$ power factor lagging , $20 \%$ total current harmonic distortion

2. $30 / 25 / 15 \mathrm{~kW}, .5$ power factor lagging , $40 \%$ total current harmonic distortion

NOTE: This specification requires the voltage source to provide $<5 \%$ THD for a given load; this is different from the manner in which utilities treat loads. Utilities restrict ${ }^{3}$ the distortion - that a user can put on the line so that other customers can be protected. The total demand

3 IEEE Std 519-1992, "IEEE Recommended Practices and Requirements for Harmonic Control in Electrical Power Systems". 
distortion (TDD) is a variable which is related to the stiffness of the grid. Thus the allowable TDD varies according to the customers location on the grid and may vary from $5 \%$ to $20 \%$ depending upon the grid stiffness.

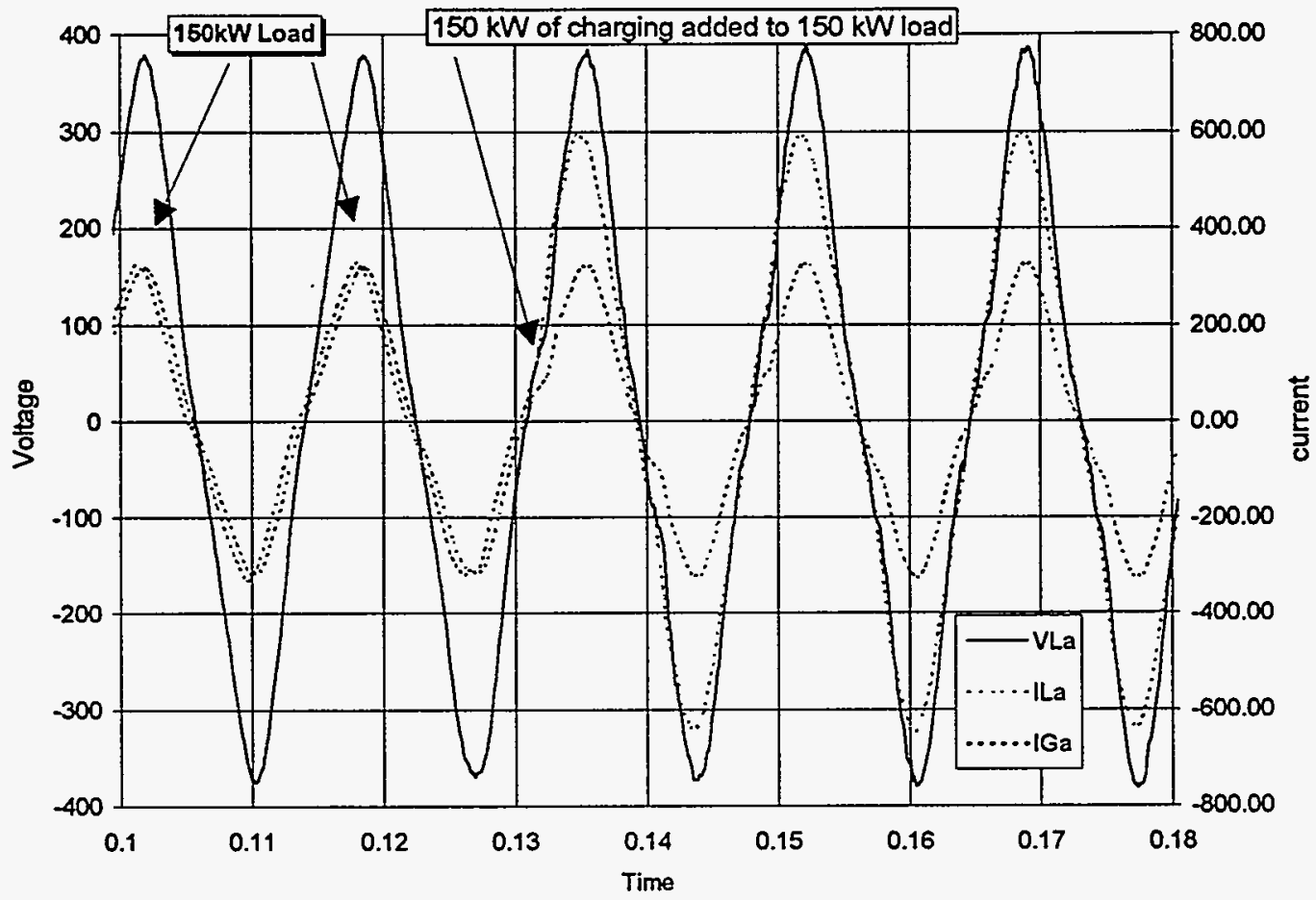

Figure 14: Addition of $150 \mathrm{~kW}$ of charge power to $150 \mathrm{~kW}$ of load power, 15 seconds after transfer from inverter to generator

In the following tests both total distortion (TD) and (THD) were recorded. The principle reason for variations in the two numbers results from the fact that the TD measurement includes noise and includes frequency components up to $30 \mathrm{kHz}$. The THD measurements are slightly lower than the TD measurements and include only harmonics up to the $50^{\text {th }}$.

\section{Test Configuration.}

PV power $=$ none

loads = nonlinear, as required to get up to $40 \%$ total current distortion for a load on phase A. Resistive and inductive loads were used in parallel with the nonlinear load for some tests. Phases B \& C were only loaded resistively.

diesel $=$ off (inverter forced on)

battery $S O C=$ nominal

\section{Detailed Test Results.}

The loads specified in the SOW could not be matched exactly. The first two sets of data results from two load that were a close match to the specified loads. The next set of data compares the distortion of the inverter to the diesel generator. The final data set contains charge-mode diesel generator distortion data.

\section{Nonlinear load number one:}

- phase $A=61 \mathrm{~kW}$, phase $B=39 \mathrm{~kW}$, phase $C=38 \mathrm{~kW}$ 
- $P F($ phase $A)=.7, P F($ phases $B \& C)=1$

The total distortion that resulted from this load was

- ac current total distortion $=16.7 \%$

- ac current total harmonic distortion $=16.3 \%$

- ac voltage total distortion $=6.1 \%$

- ac voltage total harmonic distortion $=5.6 \%$

- ac distortion for an individual harmonic $=3.3 \%$

Figure 15 displays the current and voltage waveforms (Figure 15-a) and their frequency spectrum (Figure 15-b\&c) which result from this load. The available loads prevented the attainment of $20 \%$ current THD when placed in parallel with a .7 PF. The observed distortion did exceed both THD 5\% and the individual harmonic $3 \%$ specification values.

\section{Nonlinear load number two.}

- phase $A=30 \mathrm{~kW}$, phase $B=7.5 \mathrm{~kW}$, phase $C=7.5 \mathrm{~kW}$

- $P F($ phase $A)=.5, P F($ phases $B \& C)=1$

The distortion that resulted from this load was

- ac current distortion $=35 \%$

- ac voltage distortion $=6.7 \%$

Again the voltage distortion exceeds the specification of $5 \%$.

Inverter distortion versus generator distortion

Nonlinear loads were paralleled with three different linear loads. First the inverter and then the generator were loaded with these loads. The loads were

1. a resistive load of $14 \mathrm{~kW}$ in parallel with increasing levels of nonlinear load

2. a reactive load of $20 \mathrm{kVA}, 7$. PF in parallel with increasing levels of nonlinear load

3. a reactive load of $30 \mathrm{kVA}, .5 \mathrm{PF}$ in parallel with increasing levels of nonlinear load

Because of the difference in the source impedance of the inverter and the generator, the identical loads do not result in identical current total distortion. The phase A power and the phase A voltage and current total distortion are plotted for the inverter (Figure 16) and for the generator (Figure 17). The voltage distortion resulting from using the generator as a source is higher than the voltage distortion resulting from using the inverter as a source. The voltage THD can be made to go above $5 \%$ for both sources.

\section{Charge mode distortion}

In order to examine the impact of charge-mode distortion, a comparison was made between distortion on the diesel engine with totally linear loading and with battery charging in parallel to linear loading. The diesel voltage total distortion increased with load up to $18.6 \%$ with a resistive load of $285 \mathrm{~kW}$. When the inverter was operated in the charge mode, there was no additional distortion. For example, at the same generator output power level of $285 \mathrm{~kW}$, when $136 \mathrm{~kW}$ was diverted by the bimode to charge the batteries, the total distortion (measured at the load) was $17.9 \%$. The voltage waveform with $17.9 \%$ TD on the load is shown in Figure 18. Since inverters in the charge mode can be large sinks of nonlinear current, the ability of this inverter to draw linear current for charging is 
important. If the charging current were very nonlinear, the loads might have difficulty operating when the generator was charging batteries.

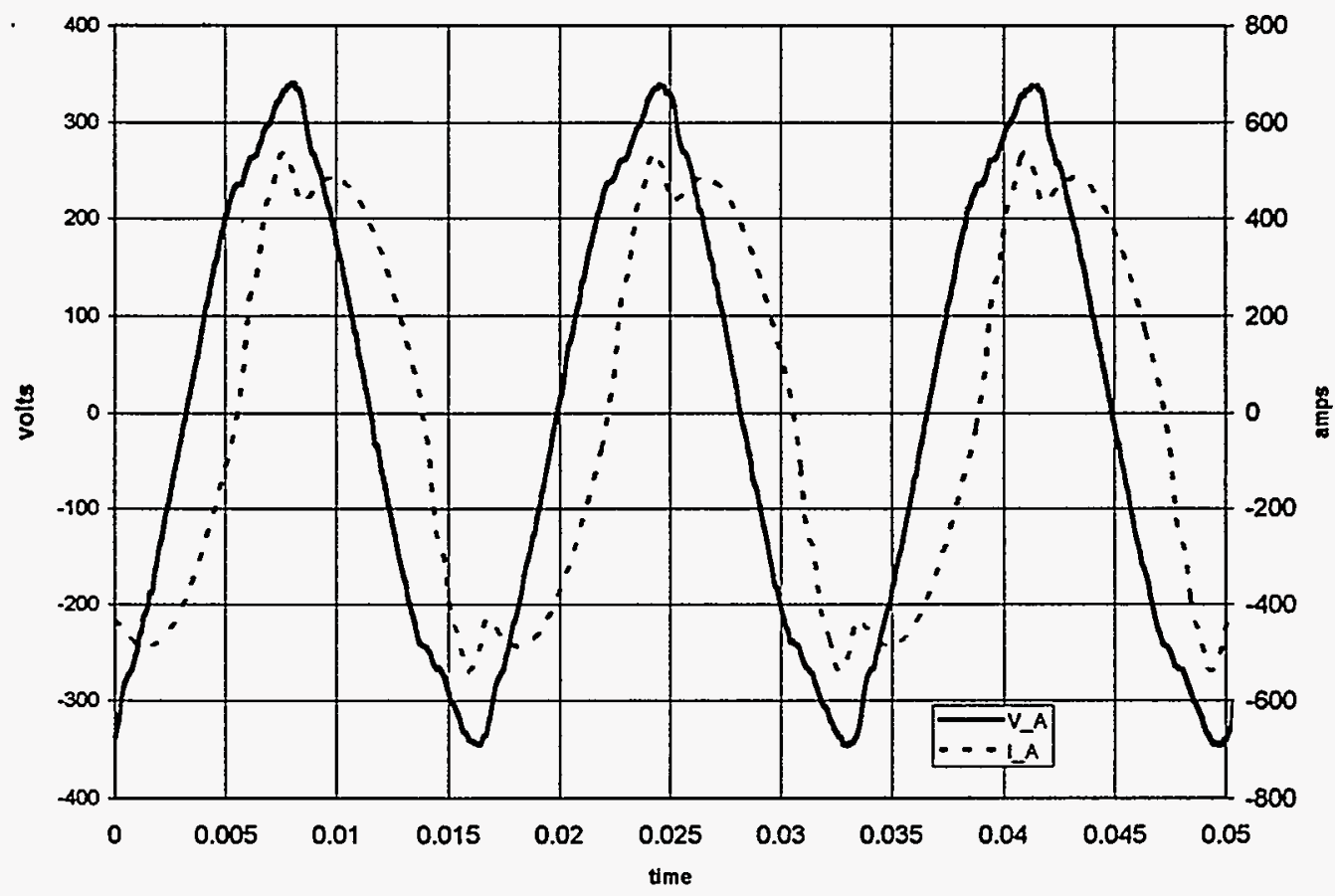

Figure 15-a. Voltage and current waveforms

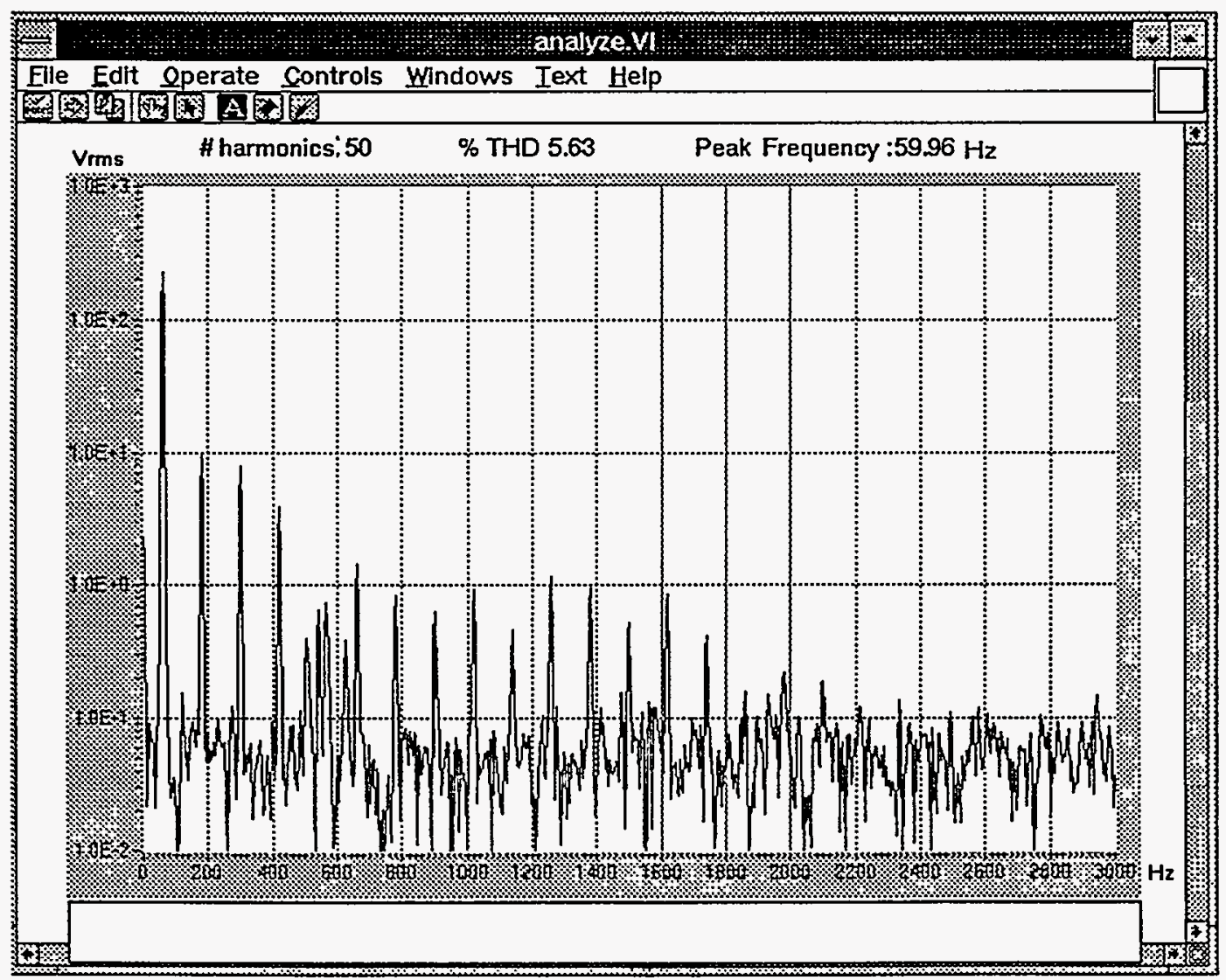


Figure 15-b. Voltage spectrum

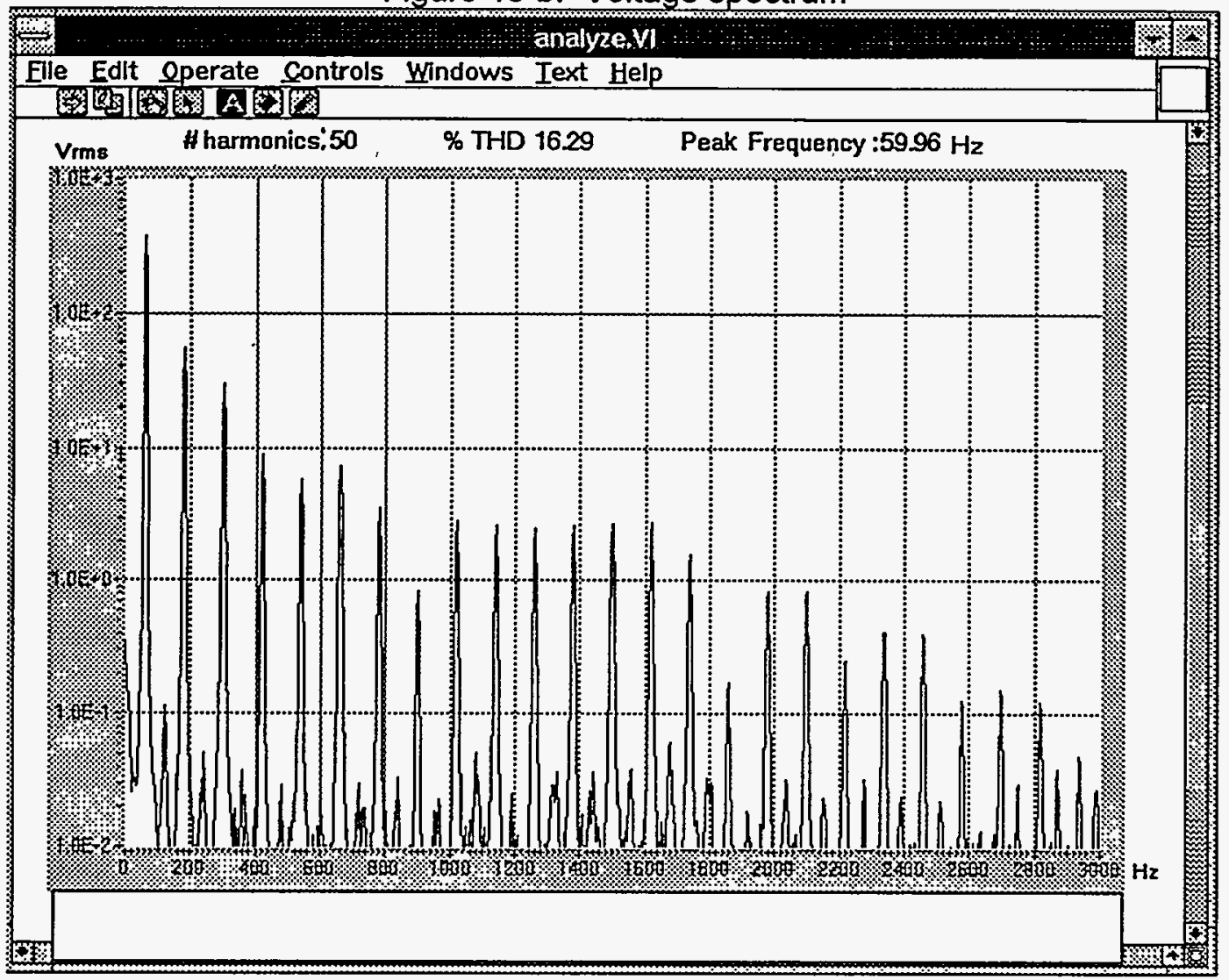

Figure 15-c. Current spectrum

Figure 15.: Nonlinear loading with $5.65 \%$ voltage total harmonic distortion (6.1\% TD)

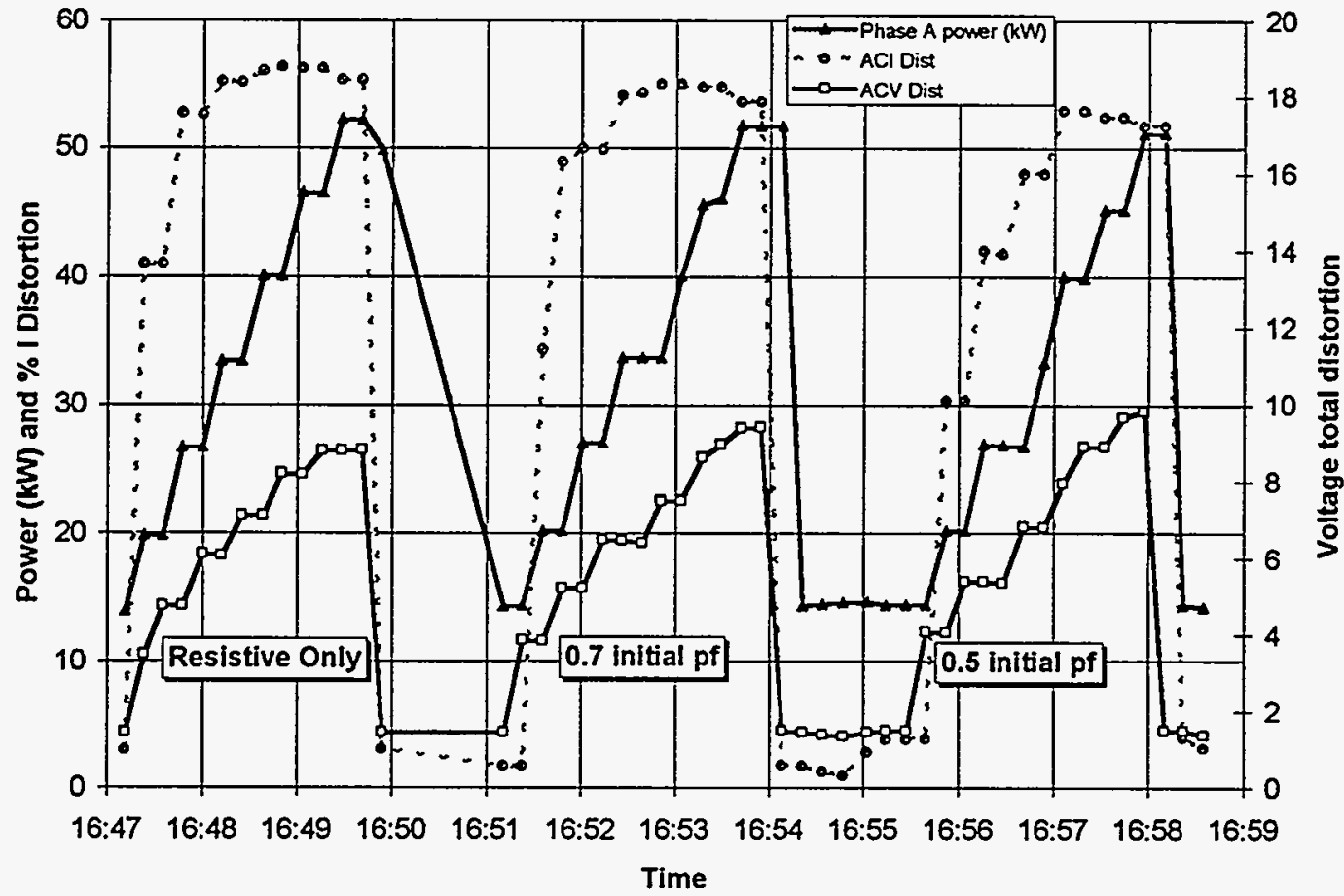

Figure 16: Inverter distortion for various loads 


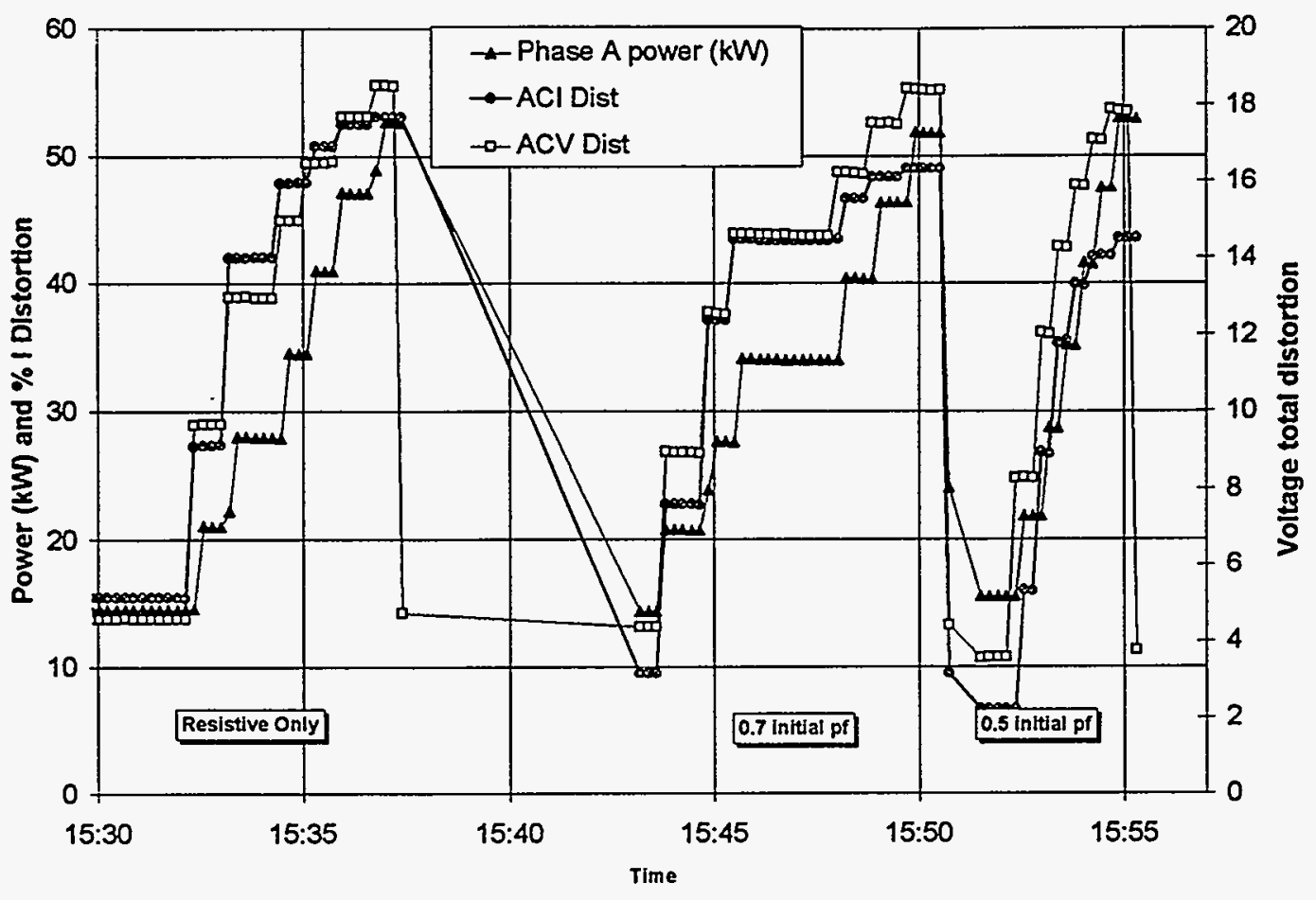

Figure 17: Generator distortion for various loads

\subsubsection{Transient Loading}

The surge power is specified to be $120 \mathrm{kVA}$ per phase for 10 seconds. Transients were provided by a combination of a 3-phase air conditioner, and resistors, as appropriate. The following transient loads were measured in this test.

- The inverter was given a base resistive load and then the building air conditioner transient was recorded. As a reference, the transient associated with the line connected air conditioner (without a resistive parallel load) was also measured. When connected to a 480 vac line, the air conditioner has a starting current of 194 amperes/phase rms. Thus the starting surge instantaneous power peaks at $65 \mathrm{kVA}$ on phase $A$ and lasts about 4 cycles when the air conditioner is connected to the line. It quickly decays to a $18 \mathrm{~kW}(\mathrm{pf}=.8$ ) three-phase load.

- A block load of $198 \mathrm{kVA}$ with a PF of .72 was applied to the inverter.

- The resistive and reactive load banks were used to achieve a transient of $120 \mathrm{kVA}$ for 10 seconds, one phase at a time. The inverter is first loaded with a balanced $150 \mathrm{~kW}$ resistive load. Then, an additional load of $50 \mathrm{~kW}$ in parallel with $65 \mathrm{kVARs}$ of inductive load is applied to a single phase.

- A $118 \mathrm{kVA} / \mathrm{ph}$ ase surge composed of a continuous resistive load of $151 \mathrm{~kW}$ balanced load with a $67 \mathrm{kVA}$ additional load on phase $A$ for a total of $118 \mathrm{kVA}, .83$ PF load on phase $A$ for 10 seconds. 


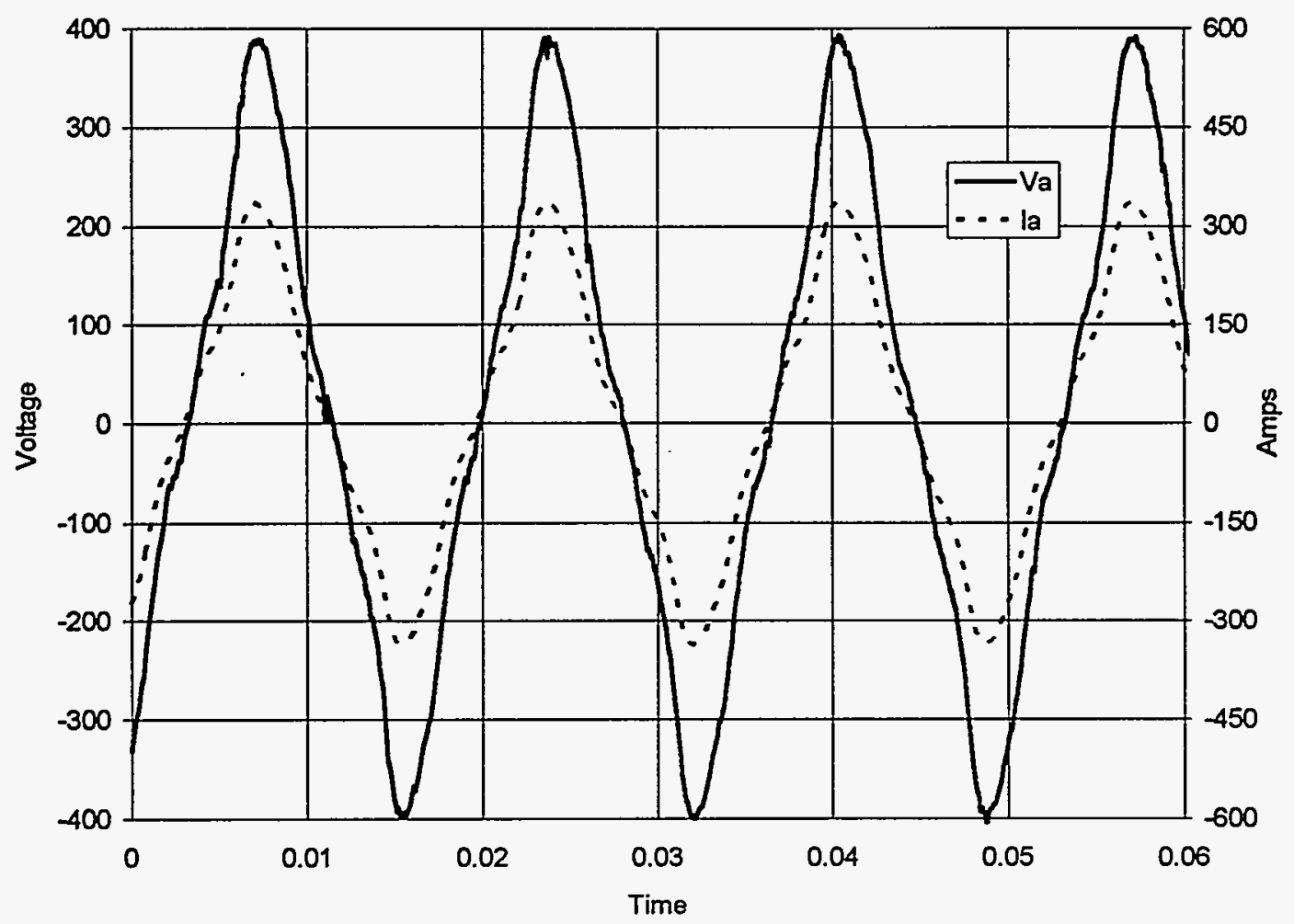

Figure 18: Using generator as source - $135 \mathrm{~kW}$ charge \& $150 \mathrm{~kW}$ load

\section{Test Configuration.}

$$
\begin{aligned}
& \text { PV power = on } \\
& \text { loads = variable } \\
& \text { diesel = off (inverter forced on) } \\
& \text { battery SOC }>\text { nominal. }
\end{aligned}
$$

\section{Detailed Test Results.}

Air conditioner loading. Prior to turning the air conditioner on (Figure 19), the inverter was configured with $200 \mathrm{kVA}$ of load ( $145 \mathrm{~kW}$ with a PF of approximately .72/phase). After turning the air conditioner on, the loading was $220 \mathrm{kVA}(160 \mathrm{~kW}$ with PF $=.72)$. The steady-state total distortion was $2 \%$ and $1.6 \%$ for the voltage and current respectively. During the turn-on transient, the sag was $2 \%$ and lasted for approximately .2 seconds. The change in the instantaneous power due to the motor starting surge is $35 \mathrm{kVA}$ on phase $\mathrm{A}$ and lasts about 10 cycles. The air conditioner then settled to a $16 \mathrm{~kW}$ three-phase load. The reduction in steady state power over the line case may result in the lower operating voltage, 233 vac for the inverter versus 265 vac for the line.

Block loading. During the block loading of the inverter (Figure 20) the load was changed from 0 to $198 \mathrm{kVA}$ with a PF of .72. A number of deviations from ideal occurred in operation. First, a transient spike was observed in the voltage waveform at .028 seconds 
on the data record. This transient caused an additional zero crossing; however, it was only

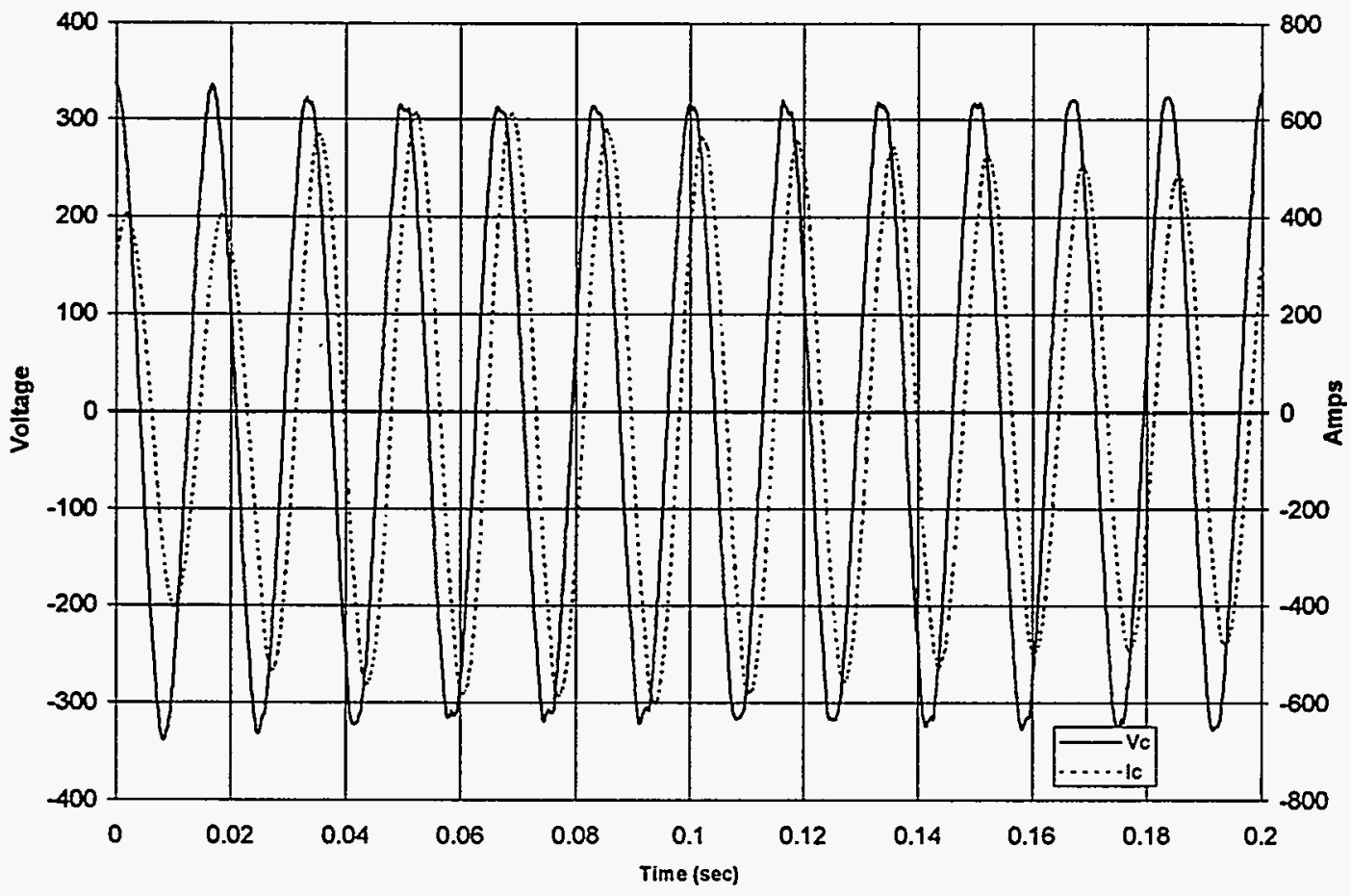

Figure 19: Air conditioner startup transient with $145 \mathrm{~kW}$ base load

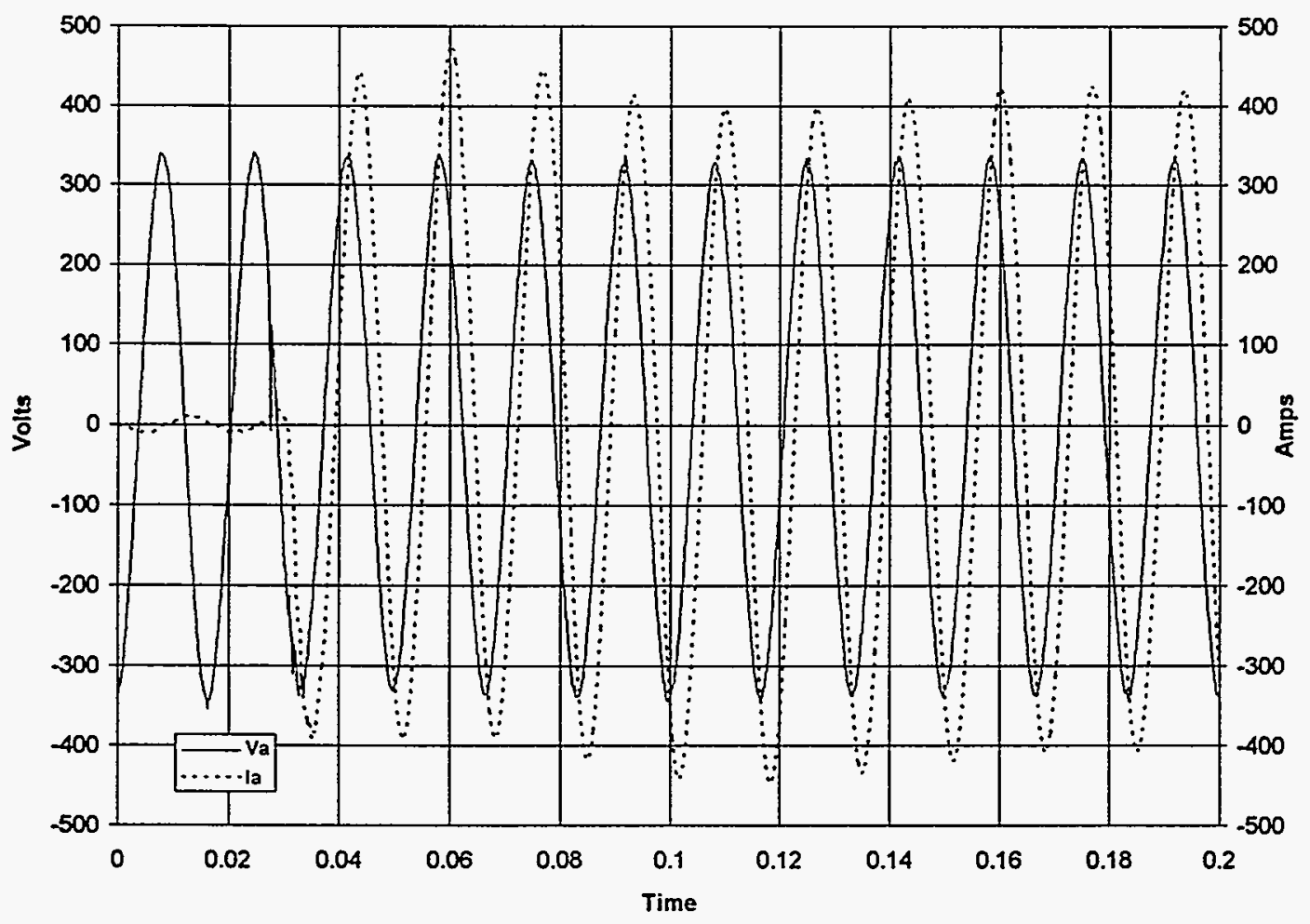

Figure 20: Block load testing of inverter, $198 \mathrm{kVA}, .72 \mathrm{PF}$ 


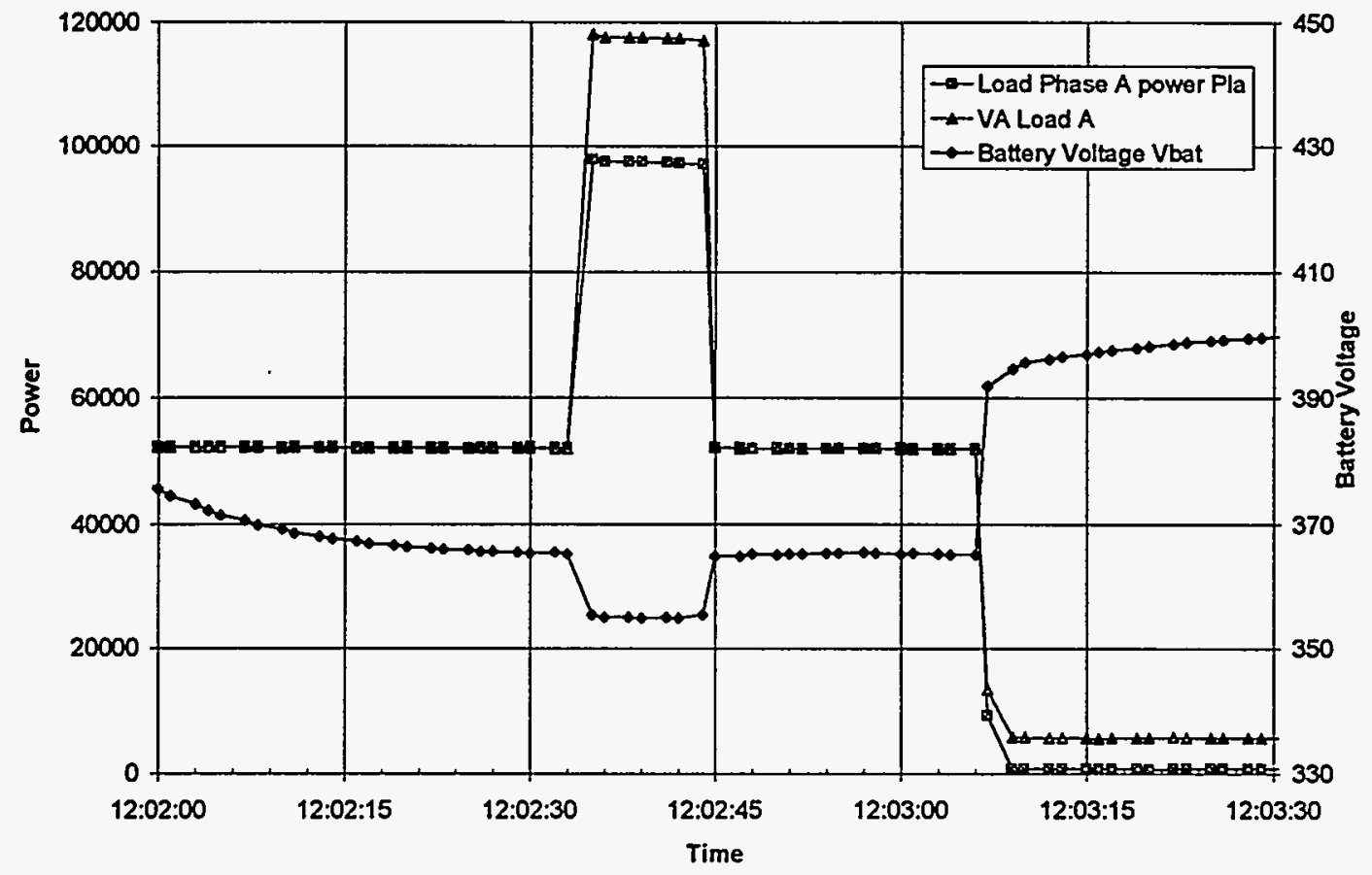

Figure 21: Ten second, $120 \mathrm{kVA}$, load

.5 milliseconds wide. The voltage sagged from 331 volts peak prior to the load application to 319 volts peak (3.6\%). The current overshot the steady-state peak value of 401 amps by 74 amps to a peak value of 475 amperes; this current overshoot had not completely decayed at .18 seconds after application of the block load. On the positive side, with 198 kVA of loading, $66 \mathrm{kVA} / \mathrm{ph} a \mathrm{se}$, the phase A distortion was $2 \%$. The inverter did meet specifications during the above test. Parameters such as sag and single-occurrence transient spikes are not addressed in the specification. It is not expected that they will adversely affect user hardware.

Loading of $120 \mathrm{kVA}$ for 10 seconds. Phase $\mathrm{A}$ was loaded with $118 \mathrm{kVA}$ for 10 seconds (Figure 21). The 10-second surge load was added to a base load of $52 \mathrm{~kW}$. The inverter functioned properly during this test.

\subsubsection{Inverter RFI}

Because RFI test results are dependent on site configuration, testing in situ is essential for this test. The RFI test was conducted at Superior Valley and the test report of the test is available as a separate document.

\subsection{Electrical Transient Protection - Tests not conducted at SNL}

\subsection{Maximum Power Tracker Evaluation}

\subsubsection{Effective dc Range}

The operating limits quantify the range of input voltages and peak power handling capability. The input operating voltage range is specified as 420 to 520 volts dc (on 
Abacus drawing 12338). This high voltage was achieved from the array simulator, while the low voltage was observed as the sun turned the MPT on. The dc voltage was measured with a calibrated meter.

\section{Test Configuration.}

PV power $=$ on for low voltage, off for high voltage

simulator $=$ on for high voltage

loads $\approx 2 \mathrm{~kW} / \mathrm{phase}$ more than the MPT supplies

diesel $=$ off (inverter forced on)

battery SOC $=$ nominal

Detailed Test Results The steps involved in this test are:

While operating with the array, the MPT began operation when its voltage exceeded the battery voltage by about 3 volts. For example, on Aug. 11 the battery voltage was 397 volts and the MPT began operation at $400 \mathrm{Vdc}$.

To examine the MPT operation at the high voltage end of its operating window, a power supply in series with the solar array simulator was connected to the MPT input. The dc input voltage to the MPT was adjusted to $600 \mathrm{Vdc}$. The MPT was turned on and would not start. The input voltage was reduced until the inverter started-that occurred at $588 \mathrm{Vdc}$. The input voltage was then adjusted by the MPT to $520 \mathrm{Vdc}$, the upper end of the MPT operating window. It is noted that the array open circuit voltage must be $\leq 588 \mathrm{Vdc}$ prior to MPT operation.

\subsubsection{Efficiency}

The efficiency of an MPT is the ratio of the output power to the input power. For use with the MPT, the nominal array voltage, specified by Abacus, is $460 \mathrm{Vdc}$ with maximum power tracking over the range of $400 \mathrm{~V}$ to $520 \mathrm{~V}$.

Test Configuration.

$$
\begin{aligned}
& \mathrm{PV}=\text { connected to MPT } \\
& \text { loads } \approx 2 \mathrm{~kW} / \text { phase more than the MPT supplies } \\
& \text { diesel = off (inverter forced on) } \\
& \text { battery } \mathrm{SOC}=\text { nominal }
\end{aligned}
$$

Detailed Test Results. The MPT was run for several days. The output power and efficiency are displayed in Figure 22 for one of these days. The data was smoothed with a five point moving average to remove noise. The clouds obstructed and enhanced the insolation as the day progressed. Just after noon, the clouds enhanced the MPT output power from $22 \mathrm{~kW}$ to $28 \mathrm{~kW}$. The efficiency was relatively invariant with power, ranging from $96 \%$ to $99 \%$, with operation at $97.5 \%$ most of the time. The MPT ac bias circuit was powered separately; however, the 11 watts required for tare operation are insignificant compared with measurement accuracy. 


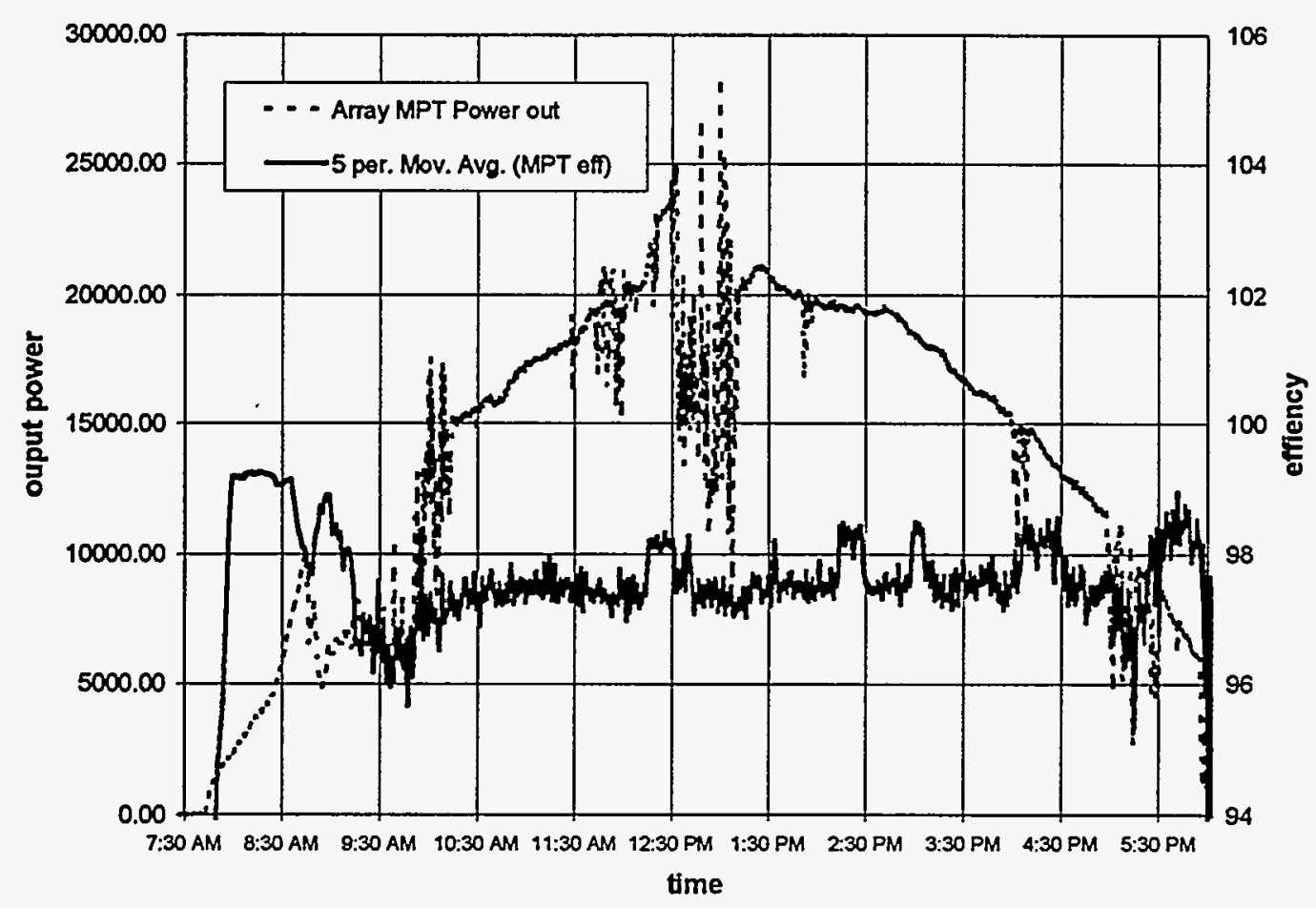

Figure 22: MPT efficiency

\subsubsection{MPT RFI}

Testing in situ is essential for this test. The RFI test is planned for Superior Valley and the test report will be available under a separate cover.

\subsection{Audible Noise}

The objective of this test is to determine the acoustic noise power in the audio spectrum that is generated by an operating power conditioning system.

The instrumentation used for these measurements was calibrated in $\mathrm{dB}$ spl with both $A$ and $C$ weighting and provided an ac output. SNL used the Bruel \& Kjaer Model 2230 Sound Level Meter with a Sound Level Calibrator. Instruments of this type include a calibrated microphone, signal conditioners, and a dB display in a single, hand-held unit

The calibrator used with the $B$ \& $K$ precision sound level meter must be within $3 \%$ of the stated frequency and $+/-1 \mathrm{~dB}$ at a level of $140 \mathrm{~dB}$. The measurement has an intrinsic accuracy of about $1 \%$, but when the random background is considered, the errors combine calibrator accuracy and measurement accuracy to give $5.1 \%$.

Detailed Test Results. The noise spectrum was recorded while in the inverter mode (150 $\mathrm{kW}$ load), while in the charge mode ( $87 \mathrm{~kW}$ ) and for the room background noise. The microphone was placed 36 inches from the front of inverter cabinet $A$. Inverter noise (see Figure 23) at the switching frequency of $5760 \mathrm{~Hz}$ and harmonics of $5760 \mathrm{~Hz}$ are significant. The MPT noise peaks (Figure 24) at the same frequency; one MPT is about $5 \mathrm{~dB}$ quieter than the six inverters. The background noise is shown in figure. 25 . The measured sound pressure level is $68 \mathrm{~dB}$, approximately $20 \mathrm{~dB}$ above the laboratory ambient. 


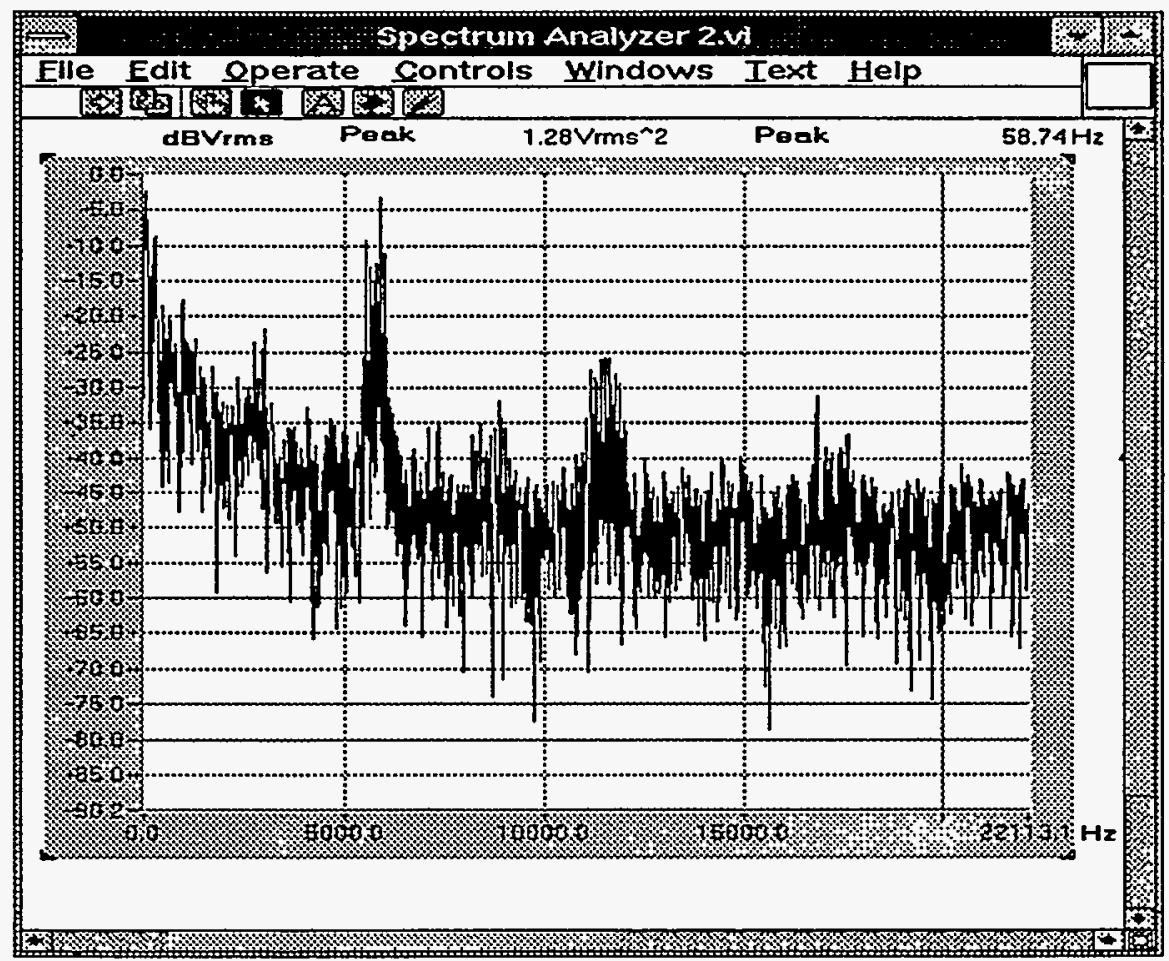

Figure 23: Noise spectrum for inverter with $150 \mathrm{~kW}$ load

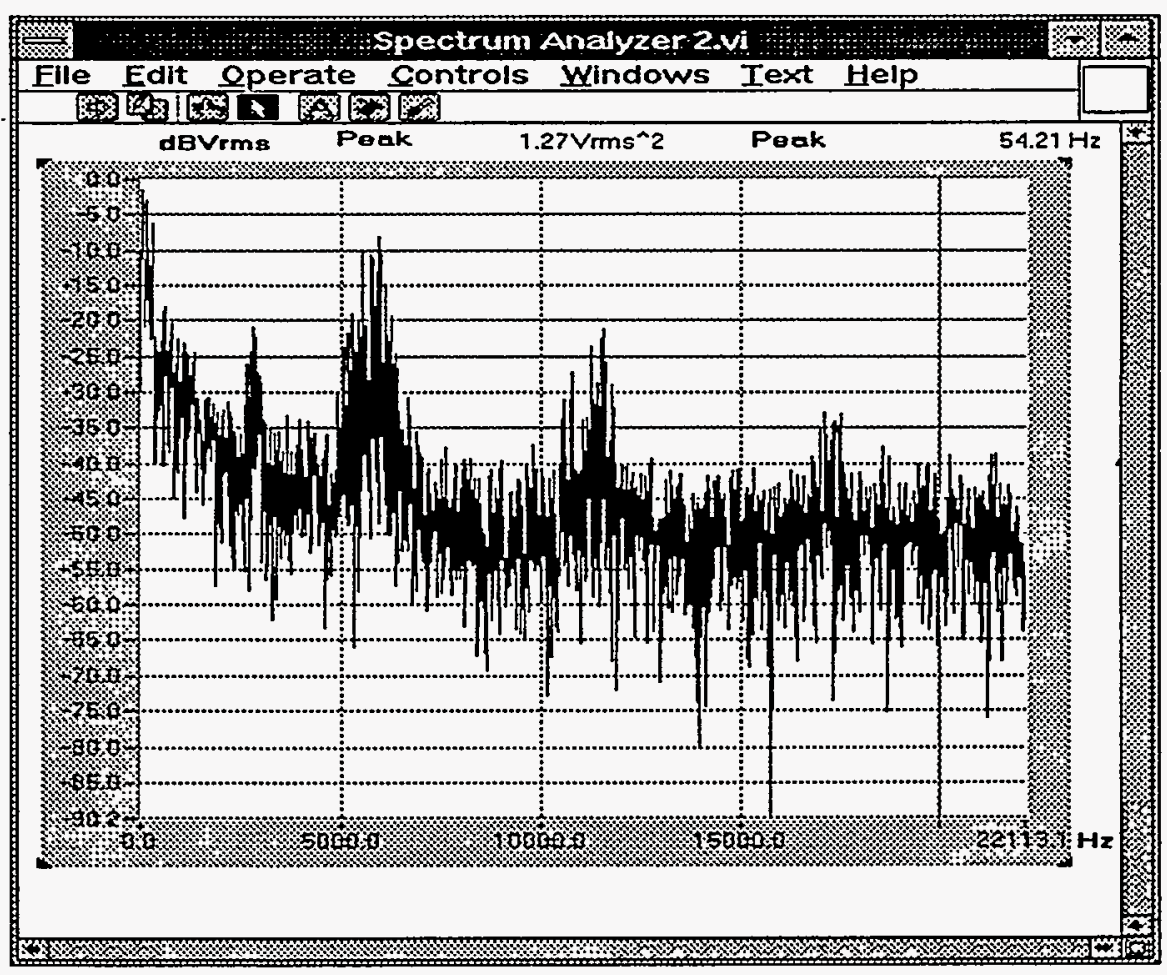

Figure 24: Noise spectrum charging battery at $87 \mathrm{~kW}$ 


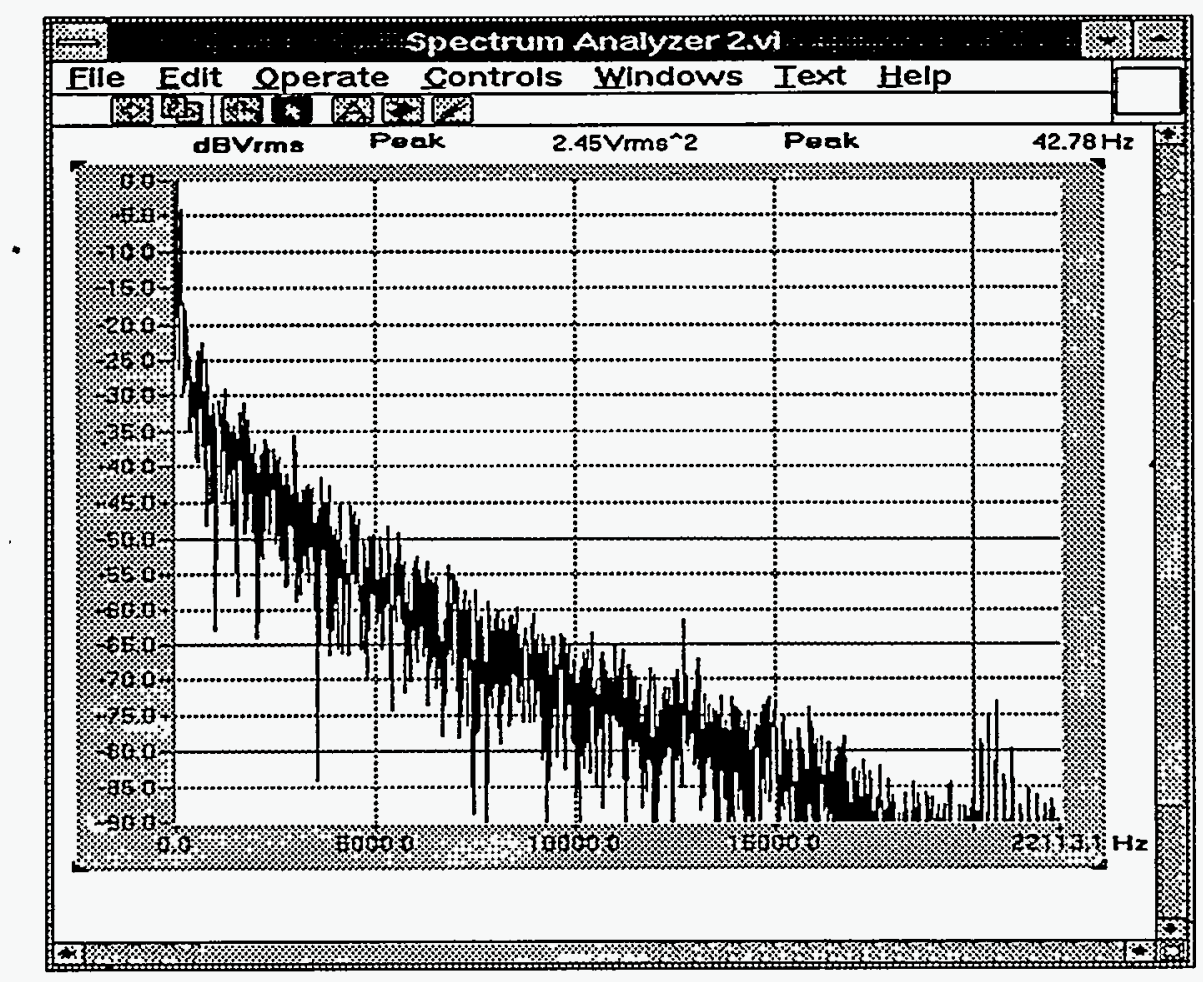

Figure 25: Noise spectrum of background 


\section{Appendix A: Measurement Matrix}

\begin{tabular}{|c|c|c|c|}
\hline & Parameter Measured & Transducer & Units \\
\hline 1 & Array Voltage Vpv & OSI VT7-12D & $\mathrm{V}$ \\
\hline 2 & Simulator Current Isim & Empro HA100-50 \& OSI VT7-16D & $\bar{A}$ \\
\hline 3 & Inverter phase B dc current ldab & Empro 400-50\& OSIVT7-16D & A \\
\hline 4 & Simulator Voltage Vsim & OSI VT7-12D & $\because$ \\
\hline 5 & Array Current Ipv & Empro HA100-50 \& OSI VT7-16D & A \\
\hline 6 & Inverter phase C dc current Idcc & Empro 400-50 \& OSI VT7-16D & A \\
\hline 7 & Battery Voltage Vbat & OSIVT7-12D & $\mathrm{V}$ \\
\hline 8 & Inverter dccurrent Idcin & Empro $1000-50$ \& OSI VT7-16D & A \\
\hline 9 & Inverter phase A dc current Idca & Empro $400-50 \&$ OSI VT7-16D & $\mathrm{A}$ \\
\hline 10 & MPT \#1 Output Current Impt1 & Empro HA100-50 \& OSI VT7-16D & $\bar{A}$ \\
\hline 11 & MPT \#2 Output Current Impt2 & Empro HA100-50 \& OSI VT7-16D & A \\
\hline 12 & Heat Sink Temperature Ta1 & Type T thermocouple & $\operatorname{deg} C$ \\
\hline 13 & Heat Sink Temperature Ta2 & Type T thermocouple & deg $C$ \\
\hline 14 & Heat Sink Temperature Tb1 & Type T thermocouple & $\operatorname{deg} C$ \\
\hline 15 & Heat Sink Temperature Tb2 & Type T thermocouple & $\operatorname{deg} C$ \\
\hline 16 & Heat Sink Temperature Tc1 & Type Thermocouple & $\operatorname{deg} \mathrm{C}$ \\
\hline 17 & Heat Sink Temperature Tc2 & Type T thermocouple & deg C \\
\hline 18 & Heat Sink Temperature Tmpt1 & Type T thermocouple & $\operatorname{deg} C$ \\
\hline 19 & Heat Sink Temperature Tmpt2 & Type T thermocouple & $\operatorname{deg} C$ \\
\hline 20 & Room Air Temperature Trm & Type T thermocouple & $\operatorname{deg} \mathrm{C}$ \\
\hline 21 & Genset Phase A Voltage Vga & Direct (fused) YEW 2533 DPM\#1 & $v$ \\
\hline 22 & Genset Phase $A$ current Iga & YEW 2241 lnst Xfmr/YEW 2533 DPM\#1 & $\bar{A}$ \\
\hline 23 & Genset Phase A power Pga & YEW 2533 DPM\#1 from $18 \& 19$ & $\bar{W}$ \\
\hline 24 & Genset Phase B Voltage Vgb & Direct ffused YEW 2533 DPM\#1 & $\because$ \\
\hline 25 & Genset Phase B current Igb & YEW 2241 inst Xfmr/YEW 2533 DPM\#1 & A \\
\hline 26 & Genset Phase B power Pgb & YEW 2533 DPM\#1 from 21822 & $\mathrm{~W}$ \\
\hline 27 & Genset Phase C voltage VgC & Direct (fused) YEW 2533 DPM\#1 & $\mathrm{V}$ \\
\hline 28 & Genset Phase $C$ current Igc & YEW 2241 Inst XfmrMEW 2533 DPM\#1 & $\mathrm{A}$ \\
\hline 29 & Genset Phase C power Pgc & YEW 2533 DPMA1 from $21 \& 22$ & $w$ \\
\hline 30 & Genset Avg Voltage Sigma Vg & YEW 2533 DPM\#1 from $18,21,824$ & $\mathrm{~V}$ \\
\hline 31 & Genset Avg Current Sigmalg & YEW 2533 DPM\#1 from 19,22,\&25 & $A$ \\
\hline 32 & Genset Total Power Sigma Pg & YEW 2533 DPM\#1 from $20,23, \& 26$ & $w$ \\
\hline 33 & Load Phase A voltage Via & Direct (fused) YEW 2533 DPM\#2 & $\mathrm{V}$ \\
\hline 34 & Load Phase A current lla & YEW 2241 inst Xfmr/YEW 2533 DPM\#2 & $\bar{A}$ \\
\hline 35 & Load Phase A power Pla & YEW 2533 DPM\#2 from $29 \& 30$ & $\bar{W}$ \\
\hline 36 & Load Phase B voltage Vib & Direct (FUSEED)IYEW 2533 DPMA2 & viv \\
\hline 37 & Load Phase B current llb & YEW 2241 inst Xfmr $/$ EW 2533 DPM\#2 & A \\
\hline 38 & Load Phase B power Plb & YEW 2533 DPM $\$ 2$ from 34 \& 35 & $\bar{W}$ \\
\hline 39 & Loaed Phase $C$ voltage Vlc & Direct (FUSED) YEW 2533 DPM\#2 & $\mathrm{V}$ \\
\hline 40 & Load Phase $C$ current lle & YEW 2241 inst Xfmr/YEW 2533 DPM\#2 & A \\
\hline 41 & Load Phase C power Plc & YEW 2533 DPMH2 from $39 \& 40$ & $w$ \\
\hline 42 & Load Avg Voltage Sigma VI & YEW 2533 DPM\#2 from $29,34, \& 39$ & $\mathrm{~V}$ \\
\hline 43 & Load Avg Current Sigma II & YEW 2533 DPM\#2 from $30,35, \& 40$ & $\bar{A}$ \\
\hline 44 & Load Total Power Sigma PI & YEW 2533 DPM\#2 from $31,36, \& 41$ & W \\
\hline 45 & Insolation & LI-Cor LI200 \& EME UTA amp & $\mathrm{W} / \mathrm{m}^{2}$ \\
\hline
\end{tabular}




\section{Appendix B: Terms and Definitions}

Parameters are defined in this section. Each of these parameters was monitored during the test program.

1. Total Harmonic Distortion (THD). . Total harmonic distortion is the ratio of the rms value of the sum of the squared individual harmonic amplitudes to the rms value of the fundamental frequency of a complex waveform. This measurement does not include noise that occurs at non harmonic frequencies. When specifying THD, it is also necessary to specify the input voltage and the type and magnitude of the load. The waveforms should be analyzed for harmonic distortion at least to the 50 th harmonic, or $3 \mathrm{kHz}$ for a $60 \mathrm{~Hz}$ system. Generally, a spectrum analyzer is used for measurement of total harmonic distortion.

$T H D=\frac{\left(H_{1}^{2}+H_{2}^{2}+\ldots \ldots \ldots+H_{n}^{2}\right)^{1 / 2}}{r m s \text { of fundamental }}$

2. Total distortion. Total distortion is a measure of the difference between a pure sine waveform of a specified frequency and a test voltage waveform, usually measured by an audio distortion analyzer. The audio analyzer can filter out the fundamental frequency to obtain the numerator of the total distortion measurement. The measurement includes random noise and other repetitive phenomena, such as slip frequencies of and not just the integer multiples of the fundamental frequency. Thus, TD is always greater than THD. The proliferation of harmonic rich loads on utility circuits, such as adjustable speed drives, lighting ballast's, computers, etc., has led to a stricter revised 1991 IEEE 519. TD is also a function of the input voltage and the type and magnitude of the load.

$T D=\frac{\text { noise }+ \text { distortion }}{\text { signal }+ \text { noise }+ \text { distortion }}$

3. Total Demand Distortion. The amount of current distortion that a user draws from a utility grid.

4. Power factor (PF). The ratio of true power to apparent power. Primarily of interest because the allowable PF defines the reactive current the inverter must supply. The PF can be measured for 3 cases $^{2}$, sinusoidal waveform, dist $<5 \%$, and dist $>5 \%$. Case 1 : PF $=\cos$ 0. Case 2: $P F=P /\left(P^{2}+Q^{2}\right)^{1 / 2}$ Where $\left(P^{2}+Q^{2}\right)^{112}=$ apparent power $(V A)$ and $Q=$ reactive power (VAR). This reduces to Case 1 when the distortion is zero. Case 3 : Sometimes referred to as the rms power factor.

$P F=\left(\frac{V_{1} I_{1} \cos \theta_{a}+V_{2} I_{2} \cos \theta_{2}+\ldots \ldots+V_{n} I_{n} \cos \theta_{n}}{\left(V_{1}^{2}+V_{2}^{2} \ldots \ldots+V_{n}^{2}\right)\left(I_{1}^{2}+I_{2}^{2} \ldots \ldots+I_{n}^{2}\right)}\right)$ where $\mathrm{n}$ is

a whole integer multiplier of the fundamental frequency, $60 \mathrm{~Hz}$. This expression is sometimes given as $P F=W /\left(V_{r m s}{ }^{*} I_{r m s}\right)$ where $W$ is the real power. The accuracy of the power meter should be $.025 \mathrm{PF}$ for waveforms with $<5 \%$ THD.

5. Displacement Power Factor. The cosine of the displacement between the voltage and the current at the fundamental frequency.

6. Rated Power. . The amount of power that can be continuously supplied to a resistive load at 25 degrees $C$, until the unit reaches thermal equilibrium. The rated power is a function of the dc input voltage.

7. Float Power/Tare Power. Power consumed by the inverter with no load 
8. Surge Power. The peak power, or surge power, is the amount of power that can be supplied to a transient load, such as a motor load for 3 seconds without interfering with normal inverter operation. The dc voltage input shall be within the manufacturer's specification range.

9. Efficiency. ,The inverter efficiency is the ratio of the output power to the average dc input power. ,The efficiency is a function of the dc input voltage and the type of load.

10. Array Ripple Current. ,The variation in dc current amplitude; dc ripple current can cause power loss by changing the operating point on an array.

11. Voltage regulation. ,The stabilization of output ac voltage against fluctuations in source or load. For a single-phase nominal $120 \mathrm{~V}$ ac system-these operating voltages are: no less than $86.7 \%$, no greater than $105.8 \%$, and nominal operating voltage. Also see ANSI C84.1-982.

12. Frequency stability. The ability of the inverter to provide a fixed $60 \mathrm{~Hz}$ output.

13. Transient Protection. The inverter should not fail as a result of electrical transients on either the dc or ac lines. No current standards exist; however, goals can be established. A specification for transient immunity is described in IEEE C62.41-1991. Additionally, the inverter should survive short circuits that are on the load side of an ac fused disconnect (see Sand 88-2974).

14. Electrical Shutdown. The inverter may be required to automatically shutdown if any of the following conditions occur.

a. Internal failure

b. Ground fault (generally refers to a fault $>5 \mathrm{~mA}$.)

C. A power drain that could result in inverter damage.

15. Temperature. The inverter will operate with the specified inverter efficiency and maximum power levels during temperature cycling. The temperature was cycled throughout the allowable temperature range.

16. Radiated Emissions.

a. Acoustic noise. Quantified by the decibel sound pressure level, dB spl. It is referenced to 20 micropascals of pressure. It is frequently weighted with an overlaid filter. The $C$ filter is a linear filter which is standardized, while the $A$ filter is an audible noise filter with a bandwidth of 500 to $5000 \mathrm{~Hz}$. For the purposes of a single noise reading in $\mathrm{dB}$, the A filter was used. Spectral information, which may be valuable for identifying the source of the noise, was recorded with the $C$ filter in use.

b. Electromagnetic or Radio Frequency Interference (EMI or RFI). Electrical emanations was examined to determine their compliance with FCC Title 47 of the Code of Federal Regulations, Part 15 "Radio Frequency Devices", Subpart J - "Computing Devices". The regulations apply to two classes of computing devices, Class A and Class B. A Class A device is marketed for use in a business/commercial/industrial area. A Class $B$ device is marketed for use in a residential environment.

17. Maximum Power Tracking. The object of the maximum power tracker is to seek the maximum power possible from the array. There are two types.

a. Perturb and observe. The controlled variable is the array voltage. During each computation period the array power is measured and compared to the power measurement from the computation period immediately preceding. If the new measurement exceeds or 
equals the old, the change in array voltage set point is in the same direction that previously caused the increase in power. If the new measurement is less than the old, the direction for the voltage set point change is reversed to seek an increase in array power.

b. The Derivative Method. Examine the derivative of power, which can be obtained by varying the voltage or current. Maximum power is achieved when the derivative is zero.

18. Voltage-source inverter. An inverter circuit in which the switches create an ac voltage from a dc voltage source 4 .

19. Current-source inverter. An inverter circuit in which the switches create an ac current from a dc voltage source ${ }^{4}$.

${ }^{4}$ Principles of Power Electronics, J. Kassakian, M. Schlecht, G. Verghese, Addison-Wesley Publishing Company, June 1992. 


\section{Appendix C: List of Abbreviations}

DG Diesel Generator

EMI Electromagnetic Interference

ODOD Operational Depth of Discharge $=40 \%$; related voltage is $350 \mathrm{Vdc}(1.82$ $\mathrm{Vdc} / \mathrm{cell}$ )

MDOD Maximum Depth of Discharge $=30 \%$; related voltage is $336 \mathrm{Vdc}(1.75$ Vdc/cell)

MPT Maximum Power Tracker

PPS Power Processing System

SC System Controller

SE System Enclosure

SPL Sound Pressure Level

SSI System Status Indicator

RFI Radio Frequency Interference 
George O'Sullivan

Abacus Controls, Inc

P.O. Box 893

Somerville, NJ 08876-0893

Robert Wills

Advanced Energy Systems, Inc.

Riverview Mill

P. O. Box 262

Wilton, NH 03086

Vahan Garboushian

Amonix, Inc.

3525 Rujita Street

Torrance, CA 90505

Tim Ball

Applied Power Corporation

1210 Homann Drive SE

Lacey, WA 98503

Bob Hammond

Arizona State University

CERS/CEAS

Tempe, AZ 85287-5806

Miles Russell

Ascension Technology, Inc.

P.O. Box 314

Lincoln Center, MA 01773

Allan Barnett

Astro Power, Inc.

Solar Park

Newark, DE 19716-2000
Lina Hellman

Advanced Energy Systems, Inc.

Riverview Mill

P. O. Box 262

Wilton, NH 03086

Ron Matlin

Advanced PV (Photovoltaic) Systems 2300 North Wayney Way

Fairfield, CA 94533

Jeff Rice

Ananda Power Tech

14618 Tyler Foote Rd.

Nevada City, CA 95969

Pete Eckert

Arizona Public Service Company

P. O. Box 53999

MS-4160

Phoenix, AZ 85072-3999

Edward Kern

Ascension Technology

P.O. Box 314

Lincoln Center, MA 01773

Juris Kalejs

ASE Americas, Inc.

4 Suburban Park Drive

Billerica, MA 01821-3980

Doug Keller

Atlantic Solar Products, Inc.

9351-J Philadelphia Road

Baltimore, MD 21237 
Joseph Bobier

Bobier Electronics, Inc.

37th and Murdoch Ave.

Parkersburg, WV 26102

Kevin Goodreau

Direct Power \& Water

3455-A Princeton NE

Albuquerque, NM 87107

Frank Goodman

Electric Power Research Institute

P.O. Box 10412

Palo Alto, CA 94303

Chuck Whitaker

Endecon Engineering

3160 Crow Canyon Rd.

Suite 240

San Ramon, CA 94583

Alan Delahoy

EPV

P. O. Box 7456

Princeton, NJ 08543

John Coors

Golden Photon

4545 Mclntyre St.

P.O. Box 4040

Golden, CO 80403

Richard Perez

Home Power Magazine

P.O. Box 130

Hornbrook, CA 96044-0130
Vern Risser

Daystar, Inc.

3240 Majestic Ridge

Las Cruces, NM 88011

Thomas Key

Electric Power Electronics Applications

Center

10521 Research Dr., Suite 400

Knoxville, TN 37932

Lee Tanner

ElectriSol Ltd.

1215 East Harmont

Phoenix, AZ 85020

Thomas Leyden

Energy Photovoltaic, Inc.

P. O. Box 7456

Princeton, NJ 08543

Lane Garrett

ETA Engineering, Inc.

8502 Cactus Wren Road

Scottsdale, AZ 85250-4907

Craig Brown

Heart Interface Corporation

21440 68th Ave. South

Kent, WA 98032-2416

Gary Seifert

INEL (Id. Nat. EngLa)

2525 Fremont Ave.

P.O. Box $1625^{\circ}$

Idaho Falls, ID 21702-3006 
Michael Daugherty

Integrated Power Corp.

7618 Hayward Rd.

Frederick, MD 21702-3006

Ken Gerken

Morningstar Corp.

2911B Olney Sandy Spring Rd.

Olney, MD 20832-1521

Dick DeBlasio

National Renewable Energy Laboratory 1617 Cole Blvd.

Golden, CO 80401

Robert Enterkine

Naval Air Warfare Center

1 Administration Circle

Code C3206

China Lake, CA 93555

Garyl Smith

Naval Weapons Center

1 Administration Circle

Code C8301/823AOOD

China Lake, CA 93555-6001

Hans Meyer

Omnion Power Electronics, Inc.

P.O. Box 879

2010 Energy Drive

East Troy, WI 53120-0879

Bob Schneider

Omnion Power Electronics, Inc.

P.O. Box 879

2010 Energy Drive

East Troy, WI 53120-0879
Bill Erdman

Kenetech

98 San Jacinto Blvd.

Suite 320

Austin, TX 78701

Charlie Gay

National Renewable Energy Laboratory 1617 Cole Blvd.

Golden, CO 80401

Roger Taylor

National Renewable Energy Laboratory 1617 Cole Blvd.

Golden, CO 80401

Mike Crom

Naval Weapons Center

Code C02A1

China Lake, CA 93555-6001

Lawrence Mott

Northern Power Systems

1 North Wind Road

Moretown, VT 05660-0659

Dave Porter

Omnion Power Electronics, Inc.

P.O. Box 879

2010 Energy Drive

East Troy, WI 53120-0879

Brad Omara

Outside Power Consultants

1803 Aiskiyou

Klamath Falls, OR 97601 
Greg Ball

Pacific Gas \& Electric Co.

PVUSA Project Office

2303 Camino Ramon, Suite 200

San Ramon, CA 94583

David Ross

Pacific Inverter, Inc.

509 Granite View Lane

Spring Valley, CA 92077

Robert Spotts

Photocomm, Inc.

7681 East Grey Road

Scottsdale, AZ 85260

Laurence Jennings

Photron, Inc.

P. O. Box 578

Willits, CA 95490-0578

Dr. Ned Mohan

Professor of Electrical Engineering

Univesity of Minnesota

200 Union St. SE

Minneapolis, MN 55455

William Kaszeta

PV Resources, Inc.

1440 W. Meseto Ave.

Mesa, AZ 85202

\section{Len Loomans}

Remote Power, Inc.

12301 North Grant St.

\#230

Denver, CO 80241-3130
Brian Farmer

Pacific Gas \& Electric Co.

PVUSA Project Office

2303 Camino Ramon, Suite 200 ..

San Ramon, CA 94583

Kevin L. Conlin

Photocomm, Inc.

13130 Stafford Road

Stafford, TX 77477

Bill Kaszeta

Photovoltaic Resources International 1902 North Country Club Drive, \#6

Mesa, AZ 85201

Arthur Sams

Polar Products

2908 Oregon Court

Building $\mathrm{K}-4$

Torrance, CA 90503

Paul Maycock

PV Energy Systems, Inc.

P. O. Box 290

Casanova, VA 22017

Clin Lashway

Raydec, Inc.

8210 La Mirada NE

Suite 700

Albuquerque, NM 87112

Dave Collier

Sacramento Municipal Utility District

6507 4th Avenue, MS-73

P.O. Box 15830

Sacramento, CA 95852-1830 
Don Osborn

Sacramento Municipal Utility District 6507 4th Avenue, MS-73

P.O. Box 15830

Sacramento, CA 95852-1830

David Wallerstein

Siemens Solar Industries

4650 Adohr Lane

P. O. Box 6032

Camarillo, CA 93011

Anoosh Mizany

Solar Depot, Inc.

61 Paul Drive

San Rafael, CA 94903

Paul McClusky

Solar Electric Specialities

P.O. Box 537

Willits, CA 95490

Jim Padula

Solar Electric Specialties

P. O. Box 537

Willits, CA 95490

Scott Sklar

Solar Energy Industries Assn.

122 C Street NW, 4th Floor

Washington, DC 20001-2109

Neil Kaminar

Solar Engineering Applications 3500 Thomas Rd., Suite E

Santa Clara, CA 95054
J. Allen Gunn

Scientific Analysis, Inc.

6012 E. Shirley Lane

Montgomery, AL 36117

Raju Yenamandra

Siemens Solar, Inc.

4650 Adohr Lane

Camarillo, CA 93010

Steven Strong

Solar Design Associates

P.O. Box 242

Harvard, MA 01451-0242

Glen Minyard

Solar Electric Specialties

P. O. Box 537

Willits, CA 95490

Keith Durand, Director

Solar Energy Industries Assn.

122 C Street NW, 4th Floor

Washington, DC 20001-2109

Clay Aldrich

Solar Energy Industries Association

122 C Street NW

Washington, DC 20001-2109

Johnny Weiss

Solar Technology Institute

P.O. Box 715

Carbondale, CO 81623-0715 
Jean Posbic

Solarex Corp.

630 Solarex Court

Frederick, MD 21701

Marshall Blalock

Southwest PV Systems, Inc.

212 East Main Street

Tomball, TX 77375

John Wiles

Southwest Technical Development Institute P.O. Box 30001

Dept. 3SOLAR

Las Cruces, NM 88003-0001

David Kulik

SunWize Energy Systems

1151 Flatbush Road

Kingston, NY 12401

Tom Lundviet

Texas Instruments

P. O. Box 655012

Dallas, TX 75265

Ray Barbee

Trace Engineering Company

5916 195th St. NE

Arlington, WA 98223

Bud Annan

U.S. Department of Energy

Forrestal Building, EE-13

1000 Independence Avenue SW

Washington, DC 20585
Ramon Dominguez

Solarex Corp

630 Solarex Ct.

Fredrick, MD 21701

Steven Durand

Southwest Technical Development Institute P.O. Box 30001

Dept. 3SOLAR

Las Cruces, NM 88003-0001

Tom Philp

Specialty Concepts, Inc.

8954 Mason Ave.

Chatsworth, CA 91311-6107

James Beck

Systems Research Group

10151 University Blvd.

Suite 171

Orlando, FL 32817

Chris Freitas

Trace Engineering Company

5916 195th St. NE

Arlington, WA 98223

Arthur Rudin

Translumin

101 Willow St.

Franklin, LA 70538-6135

Alec Bulawka

U.S. Department of Energy

Forrestal Building, EE-13

1000 Independence Avenue SW

Washington, DC $\quad 20585$ 
Mike Pulscak

U.S. Department of Energy

Forrestal Building, EE-13

1000 Independence Avenue SW

Washington, DC 20585

Mike Davis

U.S. Department of Energy

Forrestal Building, Room 8G-033

1000 Independence Avenue SW

Washington,, DC 20585

Mike Stern

Utility Power Group

9410 DeSoto Ave.

Unit $\mathrm{G}$

Chatsworth, CA 91311-4947

Wattsun Corp.

B14 2nd St. SW

Albuquerque, NM 87103

MS-0753 C.P. Cameron, 6218

MS-0753 T. Baca, 6218

MS-0753 R. Bonn, 6218 (10)

MS-0753 W.I. Bower, 6218

MS-0753 J.E. Cannon, 6218

MS-0753 R.N. Chapman, 6218

MS-0753 S. Harrington, 6218

MS-0753 R R. Hill, 6218

MS-0753 T.D. Hund, 6218

MS-0753 W. Louis, 6218

MS-0753 R.C. Pate, 6218

MS-0753 H.N. Post, 6218

MS-0753 M. Ralph, 6218

MS-0753 J.W. Stevens, 6218

MS-0753 M.G. Thomas, 6218

MS-0702 D.E. Arvizu, 62100

MS-0753 PV Library, 6218/6219 (5)

MS-0752 M.L. Tatro, 6219

MS-0899 Technical Library, 4414 (5)

MS-0619 Print Media, 12615

MS-0100 Document Processing for DOE/OSTI, 7613-2(2)

MS-0918 Central Technical Files, 8523-2
Jim Rannels

U.S. Department of Energy

Forrestal Building, EE-131

1000 Independence Avenue SW

Washington, DC 20585

Larry Slomenski

United Solar Systems Corp.

5728 Eastgate Mall

San Diego, CA 92121-2814

Rick West

Utility Power Group

4444 Orcutt Rd.

San Luis Obispo, CA 93401

David Goeser

Westinghouse Electric Corp.

Advanced Energy Systems Division

P.O. Box 355

Pittsburgh, PA 15230 



.




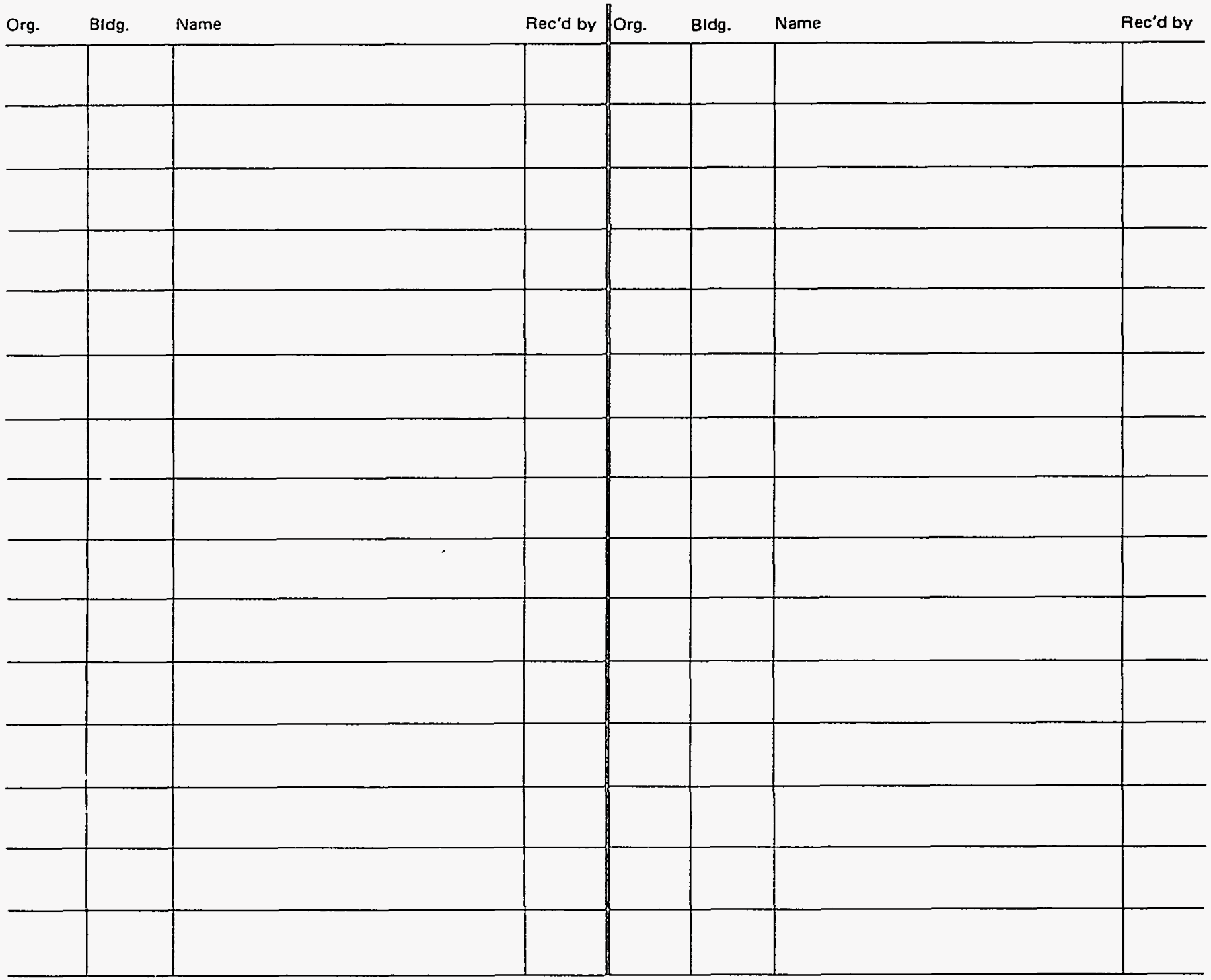

(圆a) Sandia Nataional Laboráarories 